\title{
Erken Çocukluk Döneminde Öğretmen Sorularının Uygulama Bazlı Kullanımlarının Bağlamsal Olarak İncelenmesi ${ }^{\star}$
}

\author{
Contextual Exploration of the Implementation-based Enactments of \\ Teacher Questions in the Early Childhood Period*
}

\author{
Kübra DEMIR ${ }^{a}$, Yılmaz SOYSAL ${ }^{b}$
}

Öz

Bu araşıımanın amacı bir erken çocukluk eğitimcisinin sınıf içi öğretimsel süreçlerde kullandığı soruların uygulama bazlı ve bağlamsal olarak incelenmesidir. Araştırmanın katıımcılarını bir erken çocukluk eğitimcisi ve 16 çocuk (60-72 aylık) olușturmaktadır. Sınıf içi uygulamalar görsel olarak kaydedilmiș ve sosyokültürel söylem analizinin bir kolu olan sistematik gözlem yaklaşımıyla analiz edilmiştir. Veri temelli ve teori yönelimli katalog (Öğretmen Soruları Kodlama Kataloğu) aracılığıyla öğretmen soruları saniye ve/veya dakika aralıklı kodlanmıștı. Soruların söylemsel işlevleri yedi kategori ve 28 alt kategori altında toplanmıștır: iletișimsel sorular, izleme soruları, değerlendirme amaçlı sorular, celdirme amaçlı sorular. delillendirme soruları, gözlem-karşılaştırma-tahmin soruları ve çıkarım amaçlı sorular. Ayrıca gözlemlenen soru türevlerinin ve oranlarının uygulama bazlı olacak şekilde öğrenenlerin sınıf ortamına getirdikleri kendi, günlük dilleri ile öğretmenin öğrenenleri götürmeye çalıștığı bilimin sosyal dili arasındaki farklııklardan ciddi derecede etkilendiği gözlemlenmiștir Buna ek olarak uygulamalardaki müzakere edilen tematik içeriğin özelliğinin öğretmenin sorularının türevlerini ve oranlarını değiştirebileceği sonucuna ulaşılmıştır. Özellikle öğretmen farkındalığı bağlamında okul öncesi öğretmenlerinin mesleki gelişimleri adına çeşitli önerilerde bulunulmuştur

Anahtar Kelimeler: Erken Çocukluk Eğitimi, Öğretmen Soruları, Öğretmen Farkındalığı, Söylem Analizi

\section{Abstract}

The purpose of the current study was to explore the questions staged by an early childhood teacher during in-class teaching processes by a contextual and implementation-based manner. The participants of the study were an early childhood educator and 16 children (60-72 months). In-class implementations were video-recorded and analysed through systematic observation approach as a branch of sociocultural discourse analysis. Through a data-based and theoryladen coding catalogue (Teacher Questions Coding Catalogue), teacher-led questions were labelled in seconds and/or minutes intervals. The discursive functions of the teacher-led questions were gathered around seven categories and 28 sub-categories: communicating questions, monitoring (framing) questions, legitimating questions, challenging questions, evidencing questions, observe-compare-predict questions, and inferencing (deducing) questions. In addition, it was observed that the typologies and proportions of the enacted questions were moderately or substantially affected by the differences between the students' everyday social languages that were brought to the classroom environment by the learners and the social language of the school science that the teacher tried to take the pupils. It was also concluded thematically-oriented specifications of the contents under negotiation during the in-class implementations seemed to change the types and proportions of the teacher-led questions. Various educational recommendations were offered for the professional development of preschool teachers, especially in the context of teacher noticing.

Keywords: Early Childhood Education, Teacher Questions, Teacher Noticing, Discourse Analysis

\section{Makale Hakkında}

Tür: Araştırma

Geliş Tarihi: 14 Haziran 2020 Kabul Tarihi: 27 Haziran 2020 Yayın Tarihi: 4 Temmuz 2020 DOI:

Sorumlu Yazar:

Kübra DEMIR İstanbul Aydın Üniversitesi İstanbul / Türkiye E-posta: kubra.demiirrr@gmail.com

\section{About the Article}

Type: Research Received: 14 June 2020 Accepted: 27 June 2020 Published: 4 July 2020 DOI: Corresponding Author Kübra DEMIR İstanbul Aydin University İstanbul / Turkey E-mail: kubra.demiirrrr@gmail.com

\section{Önerilen APA Atıf Biçimi / Suggested APA Citation}

Demir, K., \& Soysal, Y. (2020). Erken çocukluk döneminde öğretmen sorularının uygulama bazlı kullanımlarının bağlamsal olarak incelenmesi. Academy Journal of Educational Sciences, 4(1), 63-80. http://dx.doi.org/10.31805/acjes.752805

\footnotetext{
* Bu makale birinci yazarın yüksek lisans tezinin bir bölümünden yararlanılarak üretilmiştir.
}

* This article was produced from a part of the first author's master's thesis.

aKübra DEMIR-ORCID: https://orcid.org/0000-0002-2110-3012

İstanbul Aydın Üniversitesi, İstanbul, Türkiye... E-posta: kubra.demiirrrr@gmail.com

İstanbul Aydin University, İstanbul, Turkey. E-mail: kubra.demiirrrr@gmail.com 


\section{Giriş}

Bu araştırmanın amacı bir erken çocukluk eğitimcisinin sınıf içi etkinliklerde kullandığı soruların türevlerini (öğretimsel, pedagojik) belirlemek ve bu soruların dinamiklerinin uygulama bazlı bağlamsal olarak incelenmesini sağlamaktır. Öğretmen soruları öğretimsel çıtıların iyileştirilmesi açısından önemli bir pozisyona sahiptir (Pontecorvo ve Sterponi, 2002; Soysal, 2018; Vogler, 2005). Bu nedenle eğitimciler geçmişten günümüze öğretmen sorularını ve eğitimsel süreçleri izleme eğiliminde olmuştur. Öğretmenin sınıf içinde kullandığı tüm pedagojik söylemsel hamlelerin (söylemler, jest ve mimikler, ses tonlamaları vs.) öğrenenler açısından etkisi büyüktür. Çünkü öğretmen etkinliklerde soruları bir araç olarak kullanarak öğrenenler tarafında oluşan bilişsel çıktıların artıp azalmasına etki edebilir (Soysal, 2019). Buna karşın öğretmenler genelde sınıf rutinlerini tekrarlama ve sağlanan müfredatı öğretme çabasına girişmektedirler (Yıldız ve Strickland, 2008; Yani, 2012). Bu nedenle öğretimsel çıktılar çoğunlukla düşük bilişsel düzeyde (Bloom Taksonomisi) seyretmektedir (Gall, 1984; Storey, 2004; Soysal, 2018). Sınıf içi öğretimsel faaliyetlerin entelektüel çıktılarının iyileştirilmesi için öğretmenlerin kendilerini pedagojik olarak güncel tutmaları ve teorik bilgilerini sınıf içi uygulamalara (etkinliklere) yansitabilmeleri gerekmektedir (Storey, 2004; Soysal, 2018; 2019; Massey, Pence, Justice ve Bowles, 2008). Bu çalışmanın amacı video temelli izleme ile öğretmenin hamlelerini sistematik olarak takip etmek ve soruların tartışma dinamikleri boyutunda bağlamsal olarak incelenmesini gerçekleştirmektir. Böylece öğretmen boylamsal olarak incelenecek ve etkinlikler sırasında kullanılan öğretimin etkililiğini tespit edilebilecektir. Ayrıca inceleme sonucunda elde edilen veriler okul öncesi öğretmenlerinin mesleki gelişimleri için yol gösterici nitelikte olabilir (Barnhart ve van Es, 2015). Buna ek olarak tüm bu tespitler öğretmenlerin daha sonraki pedagojik kararlarını da destekleyecek ve böylece öğretimsel çıktının entelektüel kalitesi de artabilecektir (Gall, 1984; Soysal, 2019). Bu noktada yapılan bağlamsal incelemelerin öğretmenlerin profesyonel gelişimlerine yol göstermesi beklenmektedir. Çünkü eğitimsel önerilerin yalnızca teorik bilgiler boyutunda sunulması, öğretmenlerin mesleki gelişimlerine bağlanmasında ve pedagojik inanç sistemleri oluşturmasında yeterince etkili ol(a)mamaktadır (Soysal ve Radmard, 2017). Bu nedenle öğretmenler sahada mevcut pratiklerini sürdürürken çoğunlukla yalnız başına sorumluluk almaktadır (Putnam ve Borko, 2000). Öğretmenin pedagojik sorumluluğunu paylaşmak onun mesleki olarak gelişebilmesi açısından önemlidir (Cheminais, 2008; MacNaughton ve Williams, 2004). Öğretim stratejilerinin, söylemlerin ve pedagojik inançların eğitimsel kaliteyi ve öğrenen bilişini ne derece etkilediğini delilleriyle gösterebilmek öğretmenlerin kendilerini mesleki olarak geliştirebilmesinin önemli ögelerinden biridir (Barnhart ve van Es, 2015: Soysal ve Radmard, 2017). Bu noktada yapılan bağlamsal çözümlemelerle (sınıf içi etkinliklerin içerik boyutunda derinlemesine incelenmesi) öğretmenin sınıfiçi uygulamalarına/etkinliklerine profesyonel olarak geri bildirim sağlanabilir ve öğretmen böylece etkinlik boyutunda nelerin ters gittiğini ya da yeniden yapılandırılması gerektiğini anlayabilir. Bu bağlamsal incelemeler öğretmen farkındalığı (teacher noticing) yaratmak adına iyi bir geri bildirim mekanizması olarak işe koşulabilir. Öğretmen farkındalığı kısaca eğitimsel süreçlerde öğretmenin hamlelerinin (sözel ve sözel olamayan-jest/mimikler vs.) farkında olması ve bu sürçeler ile ilgili bilinçli bir farkındalığının oluşmasısürdürülmesi olarak tanımlanabilir (Sherin ve van Es, 2011).
Bu bilinçli farkındalık ise öğretmenler ve alan uzmanları tarafından yapılan öğretimsel incelemelerin pedagojik kanıt olarak kullanıp sonraki tecrübeleri için anlamlı çıkarımlar yapabilmesi açısından eğitimcilere destek olabilir (Morris, 2006).

\section{Teorik Çerçeve}

\section{Öğretmen Soruları ve Söylem Ilişkileri}

Soru sormak, eğitimcilerin öğrenme-öğretme hedeflerine ulaşmak için çoğunlukla kullandıkları önemli stratejilerden biridir. Çocuklar dünyaya merak duygusuyla gelirler ve konuşmaya başladıkları andan itibaren sorular sormaya başlarlar sordukları sorularla dünyayı anlamlandıırlar. Çocukların bu duygusunun geliştirilmesi, var olan keşif duygularının devam etmesi, çeşitlenmesi öğretmenlerden (yetişkinlerden) gelen soruların niteliği ile yakından ilişkilidir (Cheminais, 2008; DeVries, Zan, Hildebrant, Edmiaston ve Sales, 2002; MacNaughton ve Williams, 2004; Soysal, 2018; 2019). Esasen çocukları eğitsel olarak anlamlı konușmalara dâhil etmek birçok eğitimcinin hedefidir (Boyd ve Galda, 2011; Haves ve Matusov, 2005). Bu hedef doğrultusunda sorular bilgi oluşturma ve öğrenme aracı olarak kabul edilmektedir (Blatchford ve Mani, 2008; Chin, 2007; Storey, 2004; Soysal, 2018). Ayrıca eğitimciler sorular aracılığıyla öğrenenleri birçok farklı sürece dâhil edebilir. Örneğin soru sorarak öğrenme sürecini başlatabilir, dersin durumunu izleyebilir, sürdürebilir ya da sonlandırabilir (Alexander, 2005). Öğretmenler soruları etkinliğin takibini sağlamakta kullanacağı gibi niteliğini değiştirerek öğrenenlerin sürece olan bilişsel katkılarını arttırmak ve onları tartışma süreçlerine bağlamak için de kullanabilir (Massey. Pence, Justice ve Bowles, 2008; Sosyal, 2018; 2019). Bu nedenle soru sormak sınıf-içi yapılandırılan süreçlerde eğitimcilerin en sık tercih ettiği söylem türlerinden biridirbirdir (de Rivera, Girolametto, Greenberg ve Weitzman, 2005; Harlen, 1999). Söylem; geniş kapsamlı olarak incelenen bir kavram olmakla birlikte eğitim bazında öğretmenin sözel ve sözel olmayan (jest-mimikler vs.) tüm ifadeleri olarak tanımlanabilir (Chin, 2007; Storey, 2004). Bu ifadeler içerisinde araştırmacılar tarafından en çok incelenen boyutu ise "öğretmen soruları" olmuştur (Bay ve Alisinanoğlu, 2012; Massey, Pence,Justice ve Bowles, 2008). Söylem türleri arasında eğitimcilerin öğretimsel süreçlerde kullandığı sorularının araştırılması birçok bakımdan önemlidir. Ilk olarak; soru sorarak öğretmenler öğrenenlere düşünmeye motive etme, meraklarını ortaya koyma, düşüncelerini yönlendirme ve kendilerini ifade etmeye teşvik etme fırsatı verir (Jegede ve Olajide, 1995). Ayrıca öğretmenler sorular ile öğrenenleri var olan düşüncelerini ortaya çıkarmak, derinleştirmek, eleştirel düşünmek, hayal kurmak, problem çözmek, tahmin etmek, varsayımsal akıl yürütmek vs. gibi süreçlere dâhil edebilir (Sosyal, 2019). Bu süreçlere ek olarak; sorular doğası gereği alıcıdan bir yanıt almak üzere tasarlandığından söylemsel olarak kritik sözlü ifadeler ortaya çıkarabilir ve böylece öğrenenlerin dil gelişimini de önemLi ölçüde etkileyebilir (De Rivera, Girolametto ve Weitzman, 2005; van Kleeck, Vander Woude ve Hammet, 2006; Yolder, Davies, Bishop ve Munson, 1994; Zucker, Justice, Piasta ve Kaderavek, 2010)

Okul öncesi dönemde çocukların merak duygusu yüksek mertebelerde seyretmektedir. Bu nedenle okul öncesi dönemde öğretmenlerin çocukları düşünmeye yönlendiren soruları, onların yüksek seviyede düşünme becerisinin gelişimini desteklemektedir (Johnston, Halocha ve Chater, 2007; 
Klein, Hammrich, Bloom ve Ragins, 2000; Soysal, 2018). Öğretmen sınıf içi etkinliklerde sorular aracılığıyla öğrenenlerden değişen bilişsel düzeylerde (düşük, orta, yüksek) talepte bulunabilir (Chin ve Osborne, 2008). Öğrenenlerde bu sorulara benzer bilişsel düzeylerde seyreden cevaplar verebilirler. Kısacası öğretmenlerin soruların türlerinin ve bilişsel seviyelerinin farkında olmaları, çocukların yüksek bilişsel seviyede düşünmelerinin desteklemesinde etkilidir (Storey, 2004). Aşağıda sınıf-içi uygulamalardan alınmış bir kesit sunulmuştur. Bu durum örnek konuşmada açıklanmaktadır.

\section{Öğretmen: Deprem nasıl olușuyor biliyor musun?}

Ögrenci: Yerin altındaki taşlar kıpırdayınca yerde hareket ediyor o zaman deprem olmuş oluyor.

Öğretmen: Peki, o taşları hareket ettiren nedir?

Öğrenci: Ağır bir şey zıplarsa o zaman olabilir.

Öğretmen: "Ağır bir şey zıpladığında yerin altındaki taşlar mı hareket ediyor" diyorsun?

Öğretmen burada öğrenenlerden cevaplarını derinleştirmesini ("Taşları hareket ettiren nedir?") ve açıklaştırmasını (ör., "Ağır bir şey zıpladığında yerin altındaki taşlar mı hareket ediyor" diyorsun?) istemektedir. Bu ve buna benzer sorularda asıl amaç öğrenenin "var olan" bilgisinin uzun süreli bellekten çağırılması yani "hatırlanması" yoluyla soruya cevap vermesidir. Görüldüğü üzere öğrenenler öğretmenin talebine benzer bir "bilişsel çaba" harcayarak soruyu yanıtlamış ve zihninde konu ile alakalı var olan bilgi parçacıklarını (ör., "Yerin altındaki taşlar kıpırdayınca yerde hareket ediyor o zaman deprem olmuş oluyor.") öğretmene sunmuştur. Burada örneklendirildiği üzere öğretimsel kalite düşük düzeyde seyretmektedir. Aşağıda yine aynı sınıf-içi uygulamadan alınmış bir kesit görülmektedir.

Öğretmen: Ama bak şimdi ne diyor S4 eğer yanardağlar patladığında deprem olsaydı bizim ülkemize gelirdi ve evlerimize zarar verebilirdi diyor? Sen ne dersin? (S: Ögrenci kodlamaları için kullanılan kisaltmadır).

\section{Öğrenci: Ama patladığında bizim ülkeye gelmedi.}

Öğrenci: Bir de bizim evlerimiz sıcaktan erimiş olurdu.

Burada ise öğretmen belirli seviyelerin birlikte kullanılmasını gerektiren yüksek düzey bilişsel talepte bulunmaktadır (ör., "Ama bak şimdi ne diyor S4 eğer yanardağlar patladığında deprem olsaydı bizim ülkemize gelirdi ve evlerimize zarar verebilirdi diyor? Sen ne dersin?"). Bu soru için öğrenenin belirli bilişsel filtrelerle bilgiyi süzmesi bunun sonucunda arkadaşının iddiasını bazı kriterler yardımıyla "değerlendirmesi" ve bir yargıda bulunması gerekmektedir. Bunun sonucunda öğrenenler de tasvir edilen bilişsel süreçleri kullanarak yüksek derecede bir "bilişsel çaba" harcamış (ör., "Ama patladığında bizim ülkeye gelmedi.", "Bir de bizim evlerimiz sıcaktan erimiş olurdu." gibi) ve bazı yargılarda bulunmuştur. Görüldüğü üzere bu diyalogdaki konuşma daha yüksek bilişsel düzeyde seyretmiştir.

Buradan çıkacak veri temelli yorum, öğretmenin sınıf içi etkinliklerde kullandığı soruların öğretimsel çıktılar boyutunda etkisinin büyük olduğudur. Bu nedenle sınıf içi etkinlikler yürütülürken öğretmenin söylemlerinin farkında olması ve sorularını uygun zamanda uygun şekilde kullanması gerekmektedir (Bay ve Alisinanoğlu, 2012). Tüm bu süreçlerin pedagojik olarak bilincinde olabilmesi içinse öğretimsel farkındalığının (teacher noticing) oluşmuş olmasına bağlıdır
(Barnhart ve van Es, 2015). Eğitim fakültelerinde ne yazık ki bu farkındalık boyutunun yalnızca teorik kısmı veril(ebil)mektedir (Star ve Strickland, 2007). Öğretmenler genelde mesleki tecrübelerinden faydalanarak sınıf içi öğretimsel faaliyetleri şekillendirmektedir (van der Veen, van Kruistum ve Michaels, 2015). Bu noktada boylamsal olarak incelenen sınıf içi faaliyetlere geri bildirimler vermek önemlidir. Bu geri bildirimlerin ise sistematik ve veri temelli olması öğretmenin pedagojik olarak inancının kasıtlı ve istendik bir biçimde farklılaşması açısından kritiktir (Sizin uygun gördüğünüz bir referans olabilir). Sınıf içi süreçlerin uygulama bazında bağlamsal olarak incelenmesi öğretmen eğitiminin planlamasının yapılmasını ve öğretmene uygun geri dönüşlerin sağlanmasını kolaylaştıracaktır. İlerleyen bölümlerde bu bağlamsal incelemenin yönü ve detaylandırıması yapılacaktır.

\section{Öğretmen Farkındalığı ve Sınıf Içi Öğretimsel Süreçler}

Küreselleşen dünyada değişen eğitim hedefleriyle birlikte yeni yaklaşımlar temel alınmaya başlamıştır. Eğitimdeki değişikliklerle birlikte öğrenme-öğretme süreçleri içerik olarak büyük ölçüde değişmiştir. Yapılandırmacı yaklaşıma göre düzenlenen süreçlerde bilgi dışsal olmaktan çok kişinin kendi zihnindeki şemalarla şekillenen bir olgu olarak ele alınmaya başlamıştır (Atay, 2003). Öğretim programların içeriği durumsal çözümlere (süreç temelli eğitim) uygun biçimde tasarlanmaya başlanmış ayrıca öğrenenlerin süreçteki konumu öğretmen-diğer öğrenenler ile sürekli etkileşim halinde olacak şekilde değiştirilmiştir. Değişen bu yaklaşımların eğitim programlarını etkilemesinin yanı sıra süreçte öğretmenlere de yeni roller getirmiştir. Böylece öğretmenler alternatif eğitim stratejilerini kullanarak çeşitli yöntem ve teknikler ile birlikte sınıf içerisinde yeni bir pozisyona sahip olmuştur. Çünkü öğretmen sınıf içi süreçlerde kullandığı stratejiler ile öğrencilerin bilişsel durumundaki dalgalanmalara doğrudan etki edebilir (Soysal, 2019). Bu nedenle değişen hedeflerin sınıf içi pratiklere yansıması için öğretmenlerin yeni rolleri benimsemesi gereklidir. Örneğin; yapılandırmacı yaklaşım ile daha çok öğrenciyi merkeze alan süreçler tasarlamalı ve öğretmen bilgiyi öğreten kişi olmaktan çıkıp yapılandırmasına yardımcı olan kişi pozisyonunu almalıdır. Bu bağlamda erken çocukluk eğitimcilerinin soruları öğrenenlerin bilgilerini yapılandırma sürecine etki eden en temel değişkenlerden biri olarak kabul edilebilir (Bay ve Alisinanoğlu, 2012). Ancak düşünme becerileri gelişmiş, sorgulayan, üretken çocuklar yetiştirmek için öğretmenlerin süreçte profesyonel soru sorucular olmaları gerekmektedir (MacNaughton ve Williams, 2004). Çünkü eğitim programları işin uygulayıcıları olan öğretmenler tarafından içselleştirilip işe koşulmadığı sürece programda hedeflenen kazanımlara ulaşılamaz. Öğretmenler sınıf içerisinde yeni durumlara ayak uydurmalı ve değişen zamanlarda uygun pedagojik hamleleri kullanabilmelidir (Soysal, 2018). Bu da ancak bilinçli bir eğitimsel destek ile sağlanabilir (Barnhart ve van Es, 2011).

Öğretimi analiz etme ve öğretmen farkındalığı temelde öğretmenin düşünme sistemlerini kavramsallaştırmak amacıyla oluşturulmuştur (Franke ve Kazemi, 2001; Santagata, Zannoni ve Stigler, 2007). Ilk olarak fark etmek terimi açıklanacak olursa; günlük dilde genel gözlemleri ifade etmek için kullanılan bir kelime dizini olduğu söylenebilir (Sherin, Jacobs ve Philipp, 2011). Örneğin; bugün havanın iyi olduğu ya da kahvenin kokusunun keskinliği fark edilen durumlara örnek olarak gösterilebilir. Eğitim ve öğretim açısından düşünüldüğünde, öğretmenin mesleki gelişi- 
mi bazında fark etmek günlük hayattakinden daha farklıdır. çünkü eğitimsel süreçlerdeki durumları fark edebilmek oldukça zorlu ve karmaşık olabilmektedir (Barnhart ve van Es, 2011). Bu nedenle öğretmenin eğitimsel süreçlerde her şeyi aynı anda kontrol etmesi mümkün olamayabilir (Sherin, Jacobs ve Philipp, 2011). Öğretmenlerin profesyonel olarak gelişebilmesi için deneyimlerinden anlamlı çıkarımlar yapabilmesi, eğitimsel süreçlerde dikkat çeken ayrıntıların kanıta dönüştürebilmesi ve gelecekteki pedagojik kararlara yön verebilmesi için sistematik olarak geri bildirim sağlanması önemlidir. Bu noktada öğretmen profesyonel bir danışmanlıkla sınıfta ortaya çıkan durumları gözlemleyebilir ve uygun müdahaleler sağlayabilir hale getirilmelidir. Ayıca sınıf içi süreçlerdeki olası yaşanabilecek durumları fark etmek ve uygun müdahaleler sağlamak öğretmenin mesleki olarak gelişmesine yardımcı olacağı gibi öğretimsel kalitenin çıktılarının da iyileşmesine destek olacaktır (Sherin, Jacobs ve Philipp, 2011). Böylece öğretmenlerin fark etme becerileri arttırılarak öğrenenlerin düşünme süreçleri iyileştirilebilecek ayrıca bir sonraki öğretimsel kararlarda daha bilinçli sorumluluklar alabilecektir. Kendine etkili geri bildirim mekanizmaları sağlayabilen eğitimciler pedagojik olarak yeniliklere daha açık birer profesyonel sorgulayıcılar olabilirler (Gelfuso ve Dennis, 2014). Öğretmen farkındalığına yönelik yapılan araştırmalarda öğretmenlerin deneyimlerden aldığı geri bildirimler hakkında anlamlı çıkarımlar yapabildiği görülmektedir (Erikson, 2011; Barnhart ve van Es, 2011; Sherin, Jacobs ve Philipp, 2011). Bu nedenle öğretmenin sınıf içerisinde gerçekleştirdiği öğretimsel süreçlere nitelikli geri bildirimler verilmesi önemlidir. Bu geri bildirimlerin niteliğini ise öğretimin doğası, konusu, öğrenenlerin ilgisi vs. gibi değişkenlerce belirlenmelidir. Çalışmanın asıl amacını öğretmenlere profesyonel destek sağlanma noktasında uygulamaların bağlamsal olarak incelenmesi oluşturmaktadır. Böylelikle öğretmenlerin bilinçli farkındalıkları veri temelli bir perspektifle sağlanabilecek ve eğitimcilerin pedagojik inançları da desteklenebilecektir.

Bu bağlamda araştırmaya yön veren araştırma soruları şu şekildedir:

1. Okul öncesi öğretmeni sınıf içi öğretimsel faaliyetler esnasında sorularını hangi söylemsel işlevlerle (nitelik-türev) kullanmıştır?

2. Okul öncesi öğretmeninin sorularının nitelik (türev) boyutunda yığılmalı oranları yüzde bazında (\%) uygulamalar boyunca değişkenlik göstermekte midir?

\section{Yöntem}

\section{Araştırma Modeli}

Araştırmada, erken çocukluk döneminde öğretmenin sorularının dinamikleri bağlamsal ve söylemsel boyutta incelenmiş̧tir. Bu bağlamda araştırma bir durum çalışmasıdır. Durum çalışmaları sınırları belirginleştirilmiş belirli sistemlerin (durum, birey, grup, etkinlik ve uygulama vs.) derinlemesine analizini ve tasvirini içermektedir (Merriam, 1998). Özellikli bir olgunun incelenmesi durum çalıșalarının temel amacıdır (Merriam, 1998). Bu çalışmadaki durumu ise belirli bir zaman aralığında gerçekleşmiş öğretmen söylemleri ve soru sorma türevleri oluşturmaktadır (Mercer, 2000; 2008). Uygulamalarda öğretmen tarafından sağlanan söylemler soru sorma türlerine bağlanarak çözümlenebilir bir olgu durumuna getirilmiştir. Bir diğer söylemle sınıf içi söylemlerin öğretmenin soru sorma pratiklerine bağlanması derinlemesine incelen- miştir. Bu amaçla çalışma bağlamında bir okul öncesi öğretmeninin sınıf içindeki soru sorma "pratikleri", "stratejileri" ya da "türleri" belirli kataloglar aracılığıyla sınıflandırılarak çözümlenebilir bir olgu durumuna getirilmiştir. Araştırmada oluşan dilsel yapı özellikleriyle ilgilenilmemiştir ve yalnızca sosyal etkileşimler bağlamında oluşan öğretmen sorularının türevlerinin incelenmesi gerçekleştirilmiştir. Sonrasında öğretmenin etkinliklerde kullanmış olduğu soru türevlerinin uygulama bazlı değişkenlik gösterip göstermediğini tespit etmek amacıyla "z puanları" hesaplanmıştır. Böylece çalışmada nitel değişkenler (uygulamalar ve öğretmenin soru türevleri) arasındaki ilişki ve bu ilişkinin yönü incelenebilmiştir.

\section{Araştırmanın Katıımcıları ve Bağlamı}

Araştırmanın katıımcılarını bir erken çocukluk eğitimcisi ve 60-72 ay aralığında bulunan 16 çocuk (7 kı \%43,75 ve 9 erkek \%56,25) oluşturmaktadır. Katıımcı öğretmen 24 yıllık iş tecrübesine sahiptir ve aynı zamanda yüksek lisans eğitimine devam etmektedir. Öğretmenin bu okuldaki toplam çalışma süresi 6 yıldır ve aynı zamanda müdür yardımcılığı pozisyonunda çalışmaktadır. Çocukların sosyo-ekonomik seviyeleri ise orta-yüksek olarak belirlenmiştir. Uygulamalar MEB'e bağlı bağımsız özel bir anaokulunda gerçekleştirilmiştir ve okul imkanları olarak oldukça iyi durumdadır. Örneğin; okulda oryantasyon tekniği uygulanmaktadır ve bu bağlamda her etkinlik saati için ayarlanmış farklı sınıflar bulunmaktadır (Fen sınıfı, Türkçe-dil sınıfı, Sanat sınıfı gibi). Ayrıca uygulamalar gerekli materyaller bakımından zenginleştirilmiş sınıflarda yürütülmüştür. Böylece öğrenenler gerçek yaşam durumlarına daha çabuk uyum sağlayabilmiş̧tir. Ayrıca katılımcı öğretmen tartışmaları yürütme süreci ile alakalı uzman bir akademisyen tarafından profesyonel bir desteğe de tabi tutulmuştur. Buna ek olarak araştırmacı da öğretmene informal olarak pedagojik destek sağlamıştır. Bu nedenle öğretmen sınıf-içi tartışmaları yüksek motivasyonla yürütebilmiştir.

\section{Sınıf-içi Uygulama Süreçleri}

Araştırmada gerçekleştirilen müzakere süreçleri öğrenen merkezli etkinliklerle okul öncesi eğitim programı baz alınarak ulaşılması gereken kazanım ve göstergeler temelinde oluşturulmuştur. Ayrıca etkinlikler oluşturulurken öğrenenlerin yaş grubu ve ilgileri göz önünde bulundurulmuştur. Uygulamalar boyunca çocukların kendi bilgilerini inşa etmeleri desteklenmiştir. Böylece öğrenenler kendi bilgilerini oluşturmaları için fırsatlar yakalayabilmiş aynı zamanda delil temelli akıl yürütmelerde yapabilmiştir. Çalışma kapsamında 13 uygulama gerçekleştirilmiştir. Uygulamalar bir dönem boyunca devam etmiştir ve hafta içerisinde seçilen bir günde okul öncesi eğitim programı baz alınarak çocukların dikkat süreleri ve ilgi-yetenekleri doğrultusunda oluşturulmuştur. Buna ek olarak; çocukların soyutlamakta güçlük çekebileceği kavramlar somutlaştırılmak için simülasyonlar-deneyler (fen etkinlikleri için) tasarlanmıştır. Örneğin; "Kış Uykusuna Yatan Hayvanlar", "Yer Çekimi", "Dünyamız Nasıl Oluştu?" gibi. Ancak bunlardan üçü pilot uygulama niteliğindedir. Bu nedenle analiz sürecine dahil edilmemiştir. Uygulamalar toplamda 360 dakika sürmüştür. Etkinlikler ile ilgili ayrıntıı bilgiler Tablo 1'de tasvir edilmiştir. "Doğal Afetler" adlı uygulama yaşanan güncel deprem olayı sonrasında öğretmenin somutlaştırmak istediği bir etkinlik olarak tasarlanmıştır ancak öğrenenlerin süreçte sosyo-duygusal olarak konunun bilimselliğinden uzak yanıtlar vermesi sebebiyle konunun işlevselliğinin gözden geçirilmesi gerektiği düşünülebilir. 


\section{Veri Toplama Süreçleri}

Veriler sınıf içerisine yerleştirilen video kayıt cihazı aracılığıyla toplanmıştır. Bununla birlikte sınıf içerisinde oluşan tüm öğretmen-öğrenen konuşmaları deşifre edilebilmiştir. Kamera; tüm müzakere süreçlerinin anlaşılmasına olanak sağlayacak şekilde konumlandırılmıştır ve etkinlikler boyunca öğretmen; teknik süreçleri eş zamanlı yürütebilmesi için yardımcı bir öğretmen tarafından desteklenmiştir. Bunun yanı sıra araştırmacı veri toplama süresince öğretmeni pedagojik olarak desteklemek amacıyla uygulamalarda bulunmuştur. Grup pilot uygulamalarla kamera kaydı süreçlerine uyum sağlayabilmiş böylece izlenme etkisiyle oluşacak yanıltıcı bir durum gözlenmemiştir. Ayrıca araştırma süresince öğrenenler için rıza onam formları aileleri aracıı̆̆ıyla alınmıştır. Buna ek olarak araştırmada öğrenenlerin ve öğretmenin olası hiçbir etik durumu ihlal etmeyeceğine dair i̇stanbul Aydın Universitesi Etik komisyon 2020/01 numaralı ve 28/01/2020 tarihli kararı ile onaylanmıştır.

\section{Veri Analizi Süreçleri}

Çalışma kapsamında erken çocukluk döneminde çeşitli amaçlara hizmet eden öğretmen sorularının saniye ve dakika aralıklı olarak analizi yapılmıştır. Sınıf-içi uygulamalar aslı korunarak deşifre edilmiştir. Deşifrelerde hem sözel hem de sözel olmayan etkileşimler (jest ve mimikler, ses tonlamaları) göz önünde bulundurulmuştur. Elde edilen veriler; öğretmenin sorularının türevlerini belirlemek amacıyla analiz edilmiştir. Ham veriler sosyokültürel analiz yaklaşımın bir kolu olan sistematik gözlem aracığıyla, sınıf içerisinde oluşan anlamların öğretmen sorularına nasıl bağlandığını belirlemek amacıyla analize tabi tutulmuştur (Mercer, 2004). Sistematik gözlemler iki aşamada gerçekleştirilmiştir. Bunlar kodlama ve sayma. Her bir öğretmen sorusu analitik bir biçimde söylemsel işlevleri, soru türleri ve içerdiği olası bilişsel talepleri belirlemek amacıyla kodlanmıştır (nitel analiz). Kodlanan soru tipleri ve bilişsel katkı düzeyleri belirli kategorilere yerleştirilmiştir. Bu işlem her bir uygulama için gerçekleştirilmiştir. Nitel kodlar her bir soru için atandıktan sonra tüm uygulamalar için yığılmalı kullanım oranları tespit edilmiştir. Uygulamalar toplamında yüzdelik hesaplamalar yapılarak soru türlerinin kullanım sıklıkları tespit edilmiştir (nicel analiz). Ardından sınıf içi uygulamalarda kullanılan soru türevlerinin bağlamsal olarak çeşitli değişkenler açısından ilişkisel incelemesinin yapılması amacıyla SPSS 20.0 kullanılarak soru türevleri arasındaki ilişkinin yönü $z$ puanları hesaplanarak belirlenmiștir. Açıklamak gerekirse $z$ puanları uygulamalarda kullanılan soruların etkinlik bazlı değişiminin takibi için hesaplanmıştır. Böylece etkinliklerde hangi soru türevinin anlamlı derecede diğerlerinden farklı olup olmadığı belirlenebilmiştir (Frankel ve Wallen, 2009).

Öğretmen Sorularını Kodlama kataloğu öğretmenin söylemsel ya da pedagojik işlevlerini belirlemek amacıyla oluşturulmuştur ve toplam yedi kategori ve 28 alt kategoriden oluşmaktadır. Böylece öğretmenin sınıf içerisinde olası olarak kullanabileceği sorular geniş bir çeşitlilikle analiz edilebilmiștir. Çünkü ÖSKK tüm soru türevlerini geniș bir yelpazede yakalayabilecek işlevselliğe sahiptir (Mercer 2010; Soysal, 2018). Bir diğer deyiş̧le ÖSKK oluşturulurken hem teorik çalışmalar temel alınmış hem de kategorilerin-alt kategorilerin karşılayamadığı öğretmen soruları için veri yönelimli olarak oluşturulan kodlar kataloğa eklenmiştir (ör., alternatif söylemleri arama, bilgiyi arama, ön öğrenmelere atıfta bulunma gibi).

Çalışmada geçerlilik ve güvenilirlik koşullarının sağlanabilmesi amacıyla birçok önlem alınmıştır. Öncelikle her bir soru için atanan kodlar hem uygulama içerisinde hem de uygulamalar arasında birbirleri ile karşılaştırılmış ve böylece iç ve dış tutarlık sağlanmaya çalışılmıştır. Ayrıca araştırmacının yanlı davranmasından dolayı oluşabilecek yanlış kodlamaların engellenebilmesi için uzman incelemesine (fen eğitiminde) tabi tutulmuştur (Creswell, 2003). Buna ek olarak; araştırmacı, katıımcı öğretmen ve alan uzmanı tartışmaların

Tablo 1. Sınıf-içi uygulamalar ve içerikleri

\begin{tabular}{|c|c|c|}
\hline Sınıf- içi Uygulamalar & $\begin{array}{l}\text { Uygulama } \\
\text { Süresi (dk) }\end{array}$ & Uygulama İçerikleri \\
\hline $\begin{array}{l}\text { Su Damlacıklarının Hikayeleri } \\
\text { (Maddenin Halleri) }\end{array}$ & 10 & $\begin{array}{l}\text { "Buhar nedir ve neden oluşur?", "Maddenin halleri nelerdir?" gibi alt başlıklarda } \\
\text { müzakere edilmiştir. }\end{array}$ \\
\hline Ağır ve Hafi f Taşlar & 31 & $\begin{array}{l}\text { "Ağırlık nedir?", "Taşların ağırlıklarını nasıl bulabiliriz?" gibi alt başlıklarda müzakere } \\
\text { edilmiştir. }\end{array}$ \\
\hline Mevsimler & 11 & $\begin{array}{l}\text { "Mevsimler neden oluşur?", "Neden yağmur, kar yağar?" ve "Kar nasıl oluşur?" gibi alt } \\
\text { başlıklarda müzakere edilmiştir. }\end{array}$ \\
\hline Dünyamız Nasıl Oluştu? & 36 & $\begin{array}{l}\text { "Dünyanın ve kıtaların oluşumu", "Ülkemizin kıtalar arasındaki konumu” gibi alt } \\
\text { başlıklarda müzakere edilmiştir. }\end{array}$ \\
\hline Engelli Kimdir? & 47 & $\begin{array}{l}\text { "Kimlere engelli denir?", "Hangi durumlar bir engel oluşturur?", Engelli insanların } \\
\text { yerinde olsak ne hissederdik?" gibi alt başlıklarda müzakere edilmiştir. }\end{array}$ \\
\hline Meslekler & 45 & $\begin{array}{l}\text { Mesleklerin tanıtımıyla başlayan süreç, (polis öğretmen, aşçı, pilot, doktor vs.) ne iş } \\
\text { yaptıkları ve toplum açısından faydaları gibi alt başlıklarla müzakere edilmiştir. }\end{array}$ \\
\hline $\begin{array}{l}\text { Yaramaz Topların Hikayesi (Yer } \\
\text { çekimi) }\end{array}$ & 35 & $\begin{array}{l}\text { "Ağır ve hafif topların yere düşme durumları değişkenlik gösterir mi?", "Toplar neden } \\
\text { yere düşüyor?", "Yer çekimi nedir?" gibi alt başlıklarda müzakere edilmiştir. }\end{array}$ \\
\hline Kış Uykusuna Yatan Hayvanlar & 52 & $\begin{array}{l}\text { "Hangi hayvanlar kış uykusuna yatar?", "Kış uykusuna neden yatarlar?" gibi alt } \\
\text { başlıklarda müzakere edilmiştir. }\end{array}$ \\
\hline İki Kafamız Olsa Ne Olurdu? & 47 & $\begin{array}{l}\text { "Iiki kafamız olsaydı ne olurdu?", "Böyle bir durum gerçekte olabilir mi?", "Onların } \\
\text { yerinde olsak ne hissederdik?" gibi alt başlıklarda müzakere edilmiştir. }\end{array}$ \\
\hline Doğal Afetler & 46 & $\begin{array}{l}\text { "Doğal afet nedir?", "Hangi olaylara neden doğal afet deriz?", "Deprem neden oluşur?" } \\
\text { gibi alt başlıklarda müzakere edilmiştir. }\end{array}$ \\
\hline
\end{tabular}


Tablo 2. Öğretmen Soruları Kodlama Kataloğu (ÖSKK))

\begin{tabular}{|c|c|c|c|}
\hline Kategori & Kodlar & Söylemsel işlevler & iltgili çalışmalar \\
\hline \multirow{7}{*}{ İletişimsel } & Derinleştirme & Öğretmen sağlanan cevabın derinleştirilmesini istiyor. & $\begin{array}{l}\text { Pimentel \& McNeill (2013), } \\
\text { Leach \& Scott (2002) }\end{array}$ \\
\hline & Açıklama isteme & $\begin{array}{l}\text { Öğretmen verilen cevabın altında yatan detayı ya da ileri } \\
\text { açıklamayı öğrenmek istiyor. }\end{array}$ & \\
\hline & Yeniden yapılandırma & $\begin{array}{l}\text { Öğretmen çocuğun cevabını herkesin anlayacağı şekil- } \\
\text { de biçimlendiriyor. }\end{array}$ & \\
\hline & Somutlaştırma & $\begin{array}{l}\text { Öğretmen verilen cevaplar için somut durumlar, } \\
\text { örnekler, analojiler istiyor. }\end{array}$ & \\
\hline & Alternatif söylemler arama & $\begin{array}{l}\text { Öğretmen sınıfta alternatif "cevapları, söylemleri" ara- } \\
\text { mak istiyor. }\end{array}$ & \\
\hline & Bilgiyi arama & $\begin{array}{l}\text { Öğretmen çocuklardan ön öğrenmelerine ait "basit } \\
\text { hatırlamalar" istiyor. }\end{array}$ & \\
\hline & $\begin{array}{l}\text { Ön öğrenmelere atıfta } \\
\text { bulunma }\end{array}$ & $\begin{array}{l}\text { Öğretmen önceki etkinliklerde konuşulan kavramlara } \\
\text { "göndermelerde" bulunuyor. }\end{array}$ & \\
\hline \multirow{6}{*}{ İzleme } & Meta söylem geliştirme & $\begin{array}{l}\text { Öğretmen önceki öğrenen düşünceleri üzerine öğren- } \\
\text { cilerin yeniden düşünmesini istiyor. }\end{array}$ & $\begin{array}{l}\text { Van Zee \& Minstrell (1997a), } \\
\text { Simon vd. (2006); Mortimer } \\
\text { \& Scott (2003) }\end{array}$ \\
\hline & Odaklama & $\begin{array}{l}\text { Öğretmen çocukların dikkatini özellikli bir cevaba } \\
\text { çekiyor. }\end{array}$ & \\
\hline & İzleme-1 (anlık) & $\begin{array}{l}\text { Öğretmen derste o anda neler konuşulduğu ve } \\
\text { tartışmanın hangi noktada olduğu ile ilgili hatırlatma } \\
\text { yapıyor. }\end{array}$ & \\
\hline & İzleme-2 (geriye) & $\begin{array}{l}\text { Öğretmen derste belli bir süre önce neler konuşulduğu } \\
\text { ve tartışmanın hangi noktada olduğu ile ilgili hatırlatma } \\
\text { yapıyor. }\end{array}$ & \\
\hline & İzleme-3 (ileriye) & $\begin{array}{l}\text { Öğretmen derste belli bir süre sonra neler konuşulacağı } \\
\text { ve tartışmanın hangi noktada olacağı ile ilgili hatırlatma } \\
\text { yapıyor. }\end{array}$ & \\
\hline & Fikir değişimini test etme & $\begin{array}{l}\text { Öğretmen öğrenenleri önceki fikirlerinin değişip değiş- } \\
\text { mediği hakkında düşünmeye yönlendiriyor. }\end{array}$ & \\
\hline \multirow{3}{*}{ Değerlendirme } & Öğrenci söylemi & $\begin{array}{l}\text { Öğretmen çocukların birbirlerinin söylediklerini değer- } \\
\text { lendirmelerini istiyor. }\end{array}$ & $\begin{array}{l}\text { Christodoulou \& Osborne } \\
\text { (2014), Simon vd. (2006) }\end{array}$ \\
\hline & Öğretmen söylemi & $\begin{array}{l}\text { Öğretmen söylediklerinin öğrenenlerce değerlendir- } \\
\text { ilmesini istiyor. }\end{array}$ & \\
\hline & Durum & $\begin{array}{l}\text { Öğretmen sağladığı bir durumun, olayın, iddianın değer- } \\
\text { lendirilmesini istiyor. }\end{array}$ & \\
\hline \multirow[t]{2}{*}{ Çeldirme } & Şeytanın avukatı & $\begin{array}{l}\text { Öğretmen çocukların iddialarının içindeki epistemolojik, } \\
\text { ontolojik ve kavramsal çelişkileri ortaya çıkarıyor. }\end{array}$ & $\begin{array}{l}\text { Christodoulou \& Osborne } \\
\text { (2014), Simon vd. (2006), } \\
\text { Jadallah vd. (2011) }\end{array}$ \\
\hline & İzleme ile çeldirme & $\begin{array}{l}\text { Öğretmen iç tutarlıığı olmayan öğrenen fikirlerini } \\
\text { karşılaştırıyor. }\end{array}$ & \\
\hline \multirow{3}{*}{ Delillendirme } & Delil kullandırma & $\begin{array}{l}\text { Öğretmen çocuğun söyledikleri ile ilgili yeterli ve uygun } \\
\text { delillerinin olup olmadığını sorguluyor. }\end{array}$ & $\begin{array}{l}\text { Oh \& Campbell (2013), } \\
\text { McNeill \& Krajcik (2011) }\end{array}$ \\
\hline & "DTAY'ye yönlendirme & $\begin{array}{l}\text { Öğretmen çocukları *Delil Temelli Akıl Yürütme durumu- } \\
\text { na yönlendiriyor. }\end{array}$ & \\
\hline & Delili ödüllendirme & $\begin{array}{l}\text { Öğretmen delil temelli akıl yürütmeyi ödüllendirip, } \\
\text { pekiştiriyor. }\end{array}$ & \\
\hline \multirow{3}{*}{ Göz-Kar-Tah } & Karşılaştırma & $\begin{array}{l}\text { Öğretmen çocukların durumları, örnekleri, iddiaları vs. } \\
\text { karşılaştırmalarını istiyor. }\end{array}$ & $\begin{array}{l}\text { Mortimer \& Scott (2003), } \\
\text { Soysal (2018) }\end{array}$ \\
\hline & Tahmin & Öğretmen öğrencilerin tahminlerde bulunmasını istiyor. & \\
\hline & Gözlem & $\begin{array}{l}\text { Öğretmen öğrenenlerden anlık gözlem yapmalarını ya } \\
\text { da gözlemsel tecrübelerini paylaşmasını istiyor. }\end{array}$ & \\
\hline Çıkarım & Sonuçlandırma & Öğretmen öğrenenlerin bir sonuca varmasını istiyor. & $\begin{array}{l}\text { Mortimer \& Scott (2003), } \\
\text { Soysal (2018) }\end{array}$ \\
\hline
\end{tabular}


içerikleriyle alakalı oluşan durumların (soru sorma stillerinin) kontrolünü sağlamak için derin müzakereler gerçekleştirmiş ve böylece öğretmenin söylemlerini ne amaçla kullandığını daha yakından takip edebilmiştir (Lincoln ve Guba, 1985). Bunun yanı sıra etkinlikler hazırlanırken öğrenenlerin içerisinde bulunduğu öğretimsel kültür göz önünde bulundurulmuştur (Merriam, 1988).

\section{Bulgular ve Tartışma}

Bu bölümde katılımcı öğretmen tarafından kullanılan soruların türevleri tanıtılmış (nitel bulgular), uygulamalar boyunca hangi sıklıkla kullanıldığı tespit edilmiş (nicel bulgular) ve soruların dinamikleri bağlamsal ve söylemsel olarak incelenmiştir (nicel analiz). Çalışmada 10 sınıf içi uygulama gerçekleştirilmiş ve soruların bağlamsal olarak incelebilmesi için "z puanlarıyla" hesaplanarak aralarındaki anlamlı ilişkinin varlığı tespit edilmişstir.

Öğretmen Sorularının Türevlerinin Belirlenmesi ve Uygulama Bazlı Kullanımların Bağlamsal Olarak incelenmesi

Öğretmen yedi farklı söylemsel amaca hizmet eden soru türevini uygulamalar boyunca belirli sıklıklarla kullanmıștır. Bunlar Tablo 3' te listelendiği üzere "iletişimsel", "izleme", "değerlendirme", "çeldirme", "delilllendirme", "gözlemkarşılaştırma-tahmin" ve "çıkarım" olarak belirlenmiştir. Buna ek olarak soruların söylemsel amaçlarını tanımlamak için 28 farklı alt kategori kullanımıştır.

Tablo 3. Öğretmen Sorularının Öğretimsel (Söylemsel) Işslevlerinin Sınıf-içi Uygulamalardaki Türevleri

\begin{tabular}{|c|c|c|}
\hline $\begin{array}{l}\text { Söylemsel (Öğretimsel) işslev (Kat- } \\
\text { egoriler) }\end{array}$ & Kodlar (Alt Kategoriler) & Örnek Söylemler \\
\hline \multirow{7}{*}{ 1. iletişimsel } & 1.1.Derinleştirme & "Peki deprem nedir o zaman?" \\
\hline & 1.2.Açıklama isteme & "Çok uzakta olduğu için mi depremi etkilemez demek istedin?" \\
\hline & 1.3.Yeniden yapılandırma & "Ağır bir şey zıpladığında yerin altındaki taşlar mı hareket ediyor" diyorsun? \\
\hline & 1.4.Somutlaştırma & $\begin{array}{l}\text { "Sonucunu bilmediğimiz şeyleri tahmin edebiliriz dedin, buna bir örnek vere- } \\
\text { bilir misin? }\end{array}$ \\
\hline & 1.5.Alternatif Söylemleri Arama & "Bu konuda başka fikri olan var mı?" \\
\hline & 1.6. Bilgiyi Arama & "Bana kış uykusuna yatan bir hayvan söyler misiniz?" \\
\hline & 1.7.Ön Öğrenmelere Atıfta Bulunma & "Biz geçen gün derste engellilerle ilgili bir etkinlik yapmıştık. Hatırlayan var mı?" \\
\hline \multirow{7}{*}{ 2. İzleme } & 2.1.Meta-söylem geliştirme & $\begin{array}{l}\text { "Sen az önce depreme meteorlar sebep olur demiştin. Sence etkisi var mı } \\
\text { gerçekten?" }\end{array}$ \\
\hline & 2.3.İzleme-1 (anlık) & "Ama şuan biz başka bir konu üzerinde tartışıyoruz değil mi çocuklar?" \\
\hline & 2.4. İzleme-2 (geriye) & "Sen az önce suyun kaynadığında azaldığını söylemiştin değil mi?" \\
\hline & 2.5. İzleme-3 (ileriye) & "Karın oluşumunu daha sonra konuşalım olur mu?" \\
\hline & 2.6.Özetleme & $\begin{array}{l}\text { "Az önce dünya güneşten uzaklaştıkça soğur ve sonbahar bittiğinde havalar } \\
\text { soğumaya başlar dedik kısaca öyle mi?" }\end{array}$ \\
\hline & 2.7.Seçme-eleme & "Arkadaşınız soğuk hava suyu buza çevirebilir dedi. Makul bir cevap değil mi?" \\
\hline & 2.8.Fikir değişimini test etme & $\begin{array}{l}\text { "Sen az önce yerin üzerinde bir şey zıplamadığı halde deprem olduğunu } \\
\text { söylemiştin, şimdi olmaz diyorsun. Fikrin mi değişti?" }\end{array}$ \\
\hline \multirow[b]{2}{*}{ 3. Değerlendirme } & 3.1.Öğrenci söylemi & $\begin{array}{l}\text { "Arkadaşınız yerin üstünde ağır bir şey zıpladığında deprem olur diyor. Katılan } \\
\text { var mı?" }\end{array}$ \\
\hline & 3.2.Öğretmen söylemi & $\begin{array}{l}\text { "Bence yeryüzünde bir şeyin zıplamasının depremle ilgisi olamaz, ne dersiniz } \\
\text { buna?" }\end{array}$ \\
\hline \multirow{2}{*}{ 4. Çeldirme } & 4.1.Şeytanın avukatı & $\begin{array}{l}\text { "O zaman yerdeki herhangi bir taşı suya koyalım büyüsün ve kıtaları oluştursun } \\
\text { olur mu?" }\end{array}$ \\
\hline & 4.2.İzleme ile çeldirme & $\begin{array}{l}\text { "Günümüzde dinozorlar yok ama yine de depremler oluyor. O zaman deprem- } \\
\text { lerin sebebi dinozorlar olabilir mi?" }\end{array}$ \\
\hline \multirow[b]{2}{*}{ 5. Delillendirme } & 5.1.Delil kullandırma & "Böyle olduğunu nereden biliyorsun peki?" \\
\hline & $\begin{array}{l}\text { 5.2.Delil temelli akıl yürütmeye } \\
\text { yönlendirme }\end{array}$ & $\begin{array}{l}\text { "Yeryüzünde bir hareketlenme olması depremi etkilemez diyorsun, depremin } \\
\text { oluşumuyla ilgili makul bir açıklaman var mı o halde?" }\end{array}$ \\
\hline \multirow{3}{*}{ 6. Gözlem-Karşılaştırma-Tahmin } & 6.1.Gözlem & "Buz nasıl bir madde sence?" \\
\hline & 6.2.Karşılaştırma & "Hangi elinizde soğuğu daha çok hissettiniz?" \\
\hline & 6.3.Tahmin & "Peki, uzun süre yetebilir mi sence yedikleri yiyecekler?" \\
\hline \multirow{2}{*}{ 7. Çıkarım } & 7.1.Sonuçlandırma & "O zaman engele sürekli o organını kullanamama durumu diyebilir miyiz?" \\
\hline & 7.2.Varsayıma yönlendirme & "O zaman engel doğuştan da olabilir öyle mi?" \\
\hline
\end{tabular}




\section{iletişimsel amaçlı öğretmen soruları}

Bu kategoride yer alan öğretmen soruları sınıfta öğretmen-öğrenci ve öğrenen-öğrenen arasında sağlıklı bir sözel ya da sözel olmayan ilişkinin kurulmasına yardımcı olmuştur. Tablo 3'te görüldüğü üzere, öğretmen iletişimsel amaçlı sorularını yedi farklı alt kategori ile sınıf içerisinde somutlaştırılmıştır. Öğretmen bu tipte sorular ile öğrenenlerin cevaplarını derinleştirmeyi ve söylemlerin daha anlaşıır olmasını sağlamayı amaçlamıştır. Böylece öğrenenler süreçlerde daha aktif rol alabilmişlerdir. Ayrıca iletişimsel sorular ile sınıfta ortak bir dil oluşturulabilmiştir. Dolasıyla öğretmen bu sorularla öğrenenlerin iddialarını eleştirmeden önce onları anlamaya, cevaplarının ardında yatan düşünceyi ortaya çıkarmaya çalışmıştır. Başka bir söylemle öğretmen iletişimsel sorular ile öncelikle öğrenenleri anlamaya çalışmış ayrıca onların da birbirini anlaması için fırsatlar yaratmıştır. Örneğin Tablo 6'da öğrenen deprem olgusuna atıfta bulunarak meteorların birbirine çarpması sonucu yanardağların patladığını ifade etmiş (Satır 6) bunun üzerine öğretmen onun söylemini anlamlandırmak için öğrenene bir "açıklama isteme" sorusu yönlendirmiştir (Satır 7). Sınıf söyleminde öğrenenlerin öğrenme-öğretme süreçlerine katkıda bulunmalarının en önemli ön koşulu diğer öğrenenlerce söylemin anlaşııması, kavranması ve ortak bir dil oluşturulmasıdır. Çünkü öğretmen temelde çocukların söylemlerini ve bunlar içerisinde gizil olan düşünme sistemlerini dışa vurabildiğinde sınıftaki tüm düşünce süreçlerini sınıfın ortak malı haline getirebilir.

İletişimsel soruların sınıf içerisinde kullanılması öğrenenlerin akıl yürütme becerilerini desteklese de bu soruların sıklıkla kullanımı diğer soru türevlerinin geri planda kalmasına sebep olabilir. Çalışmada da tasvir edilen sürece paralel olarak iletişimsel sorular en yüksek tercih edilme oranına sahip kategori olarak tespit edilmiştir. Tablo 4'te de ayrıntılı görüldüğü üzere öğretmen sorularının en yüksek kullanım oranlarını iletişimsel sorular oluşturmaktadır. Öğretmen pilot uygulamalardan hemen sonra gerçekleştirdiği ilk uygulamasında (Su Damlacıklarının Hikayeleri (Maddenin Halleri)) iletişimsel soruları (\%52,78 z: 1,58) oranında kullanmıştır. Öğretmen bu etkinlikte öğrenenlere çoğunlukla açılama isteme ( $\mathrm{Ne}$ dediğini anlamadım? Biraz daha açıklar mısın?), derinleştirme (Bunu detaylandırabilir misin?) alternatif söylemleri arama (Başka fikri olan var mı?) gibi sorular yöneltmiştir. Bu da grubun tartışmaya bilişsel olarak bağlanmasından daha çok kendini açıklama ifade etme süreçlerine girişmesine sebep olmuştur. Açıklanacak olursa; öğretmen çoğunlukla çocuklara iletişimsel türde soruları "O zaman sen sıcaklığın sebebi güneş mi diyorsun?" yönlendirmişstir. Bu durum "değerlendirme" ve "çeldirme" sorularının daha az tercih edilmesine sebep olmuş olabilir. Çünkü iletişimsel hamlelerin yoğun kullanımı tartışmaya bilişsel olarak bağlanmaktan çok öğrenenlerin art alan düşüncelerini açığa çıkarmayı sağlamıştır. Bunun sonucunda öğrenenler kendilerinin ya da sınıfta oluşan söylemlerin üzerine düşünmekten ziyade cevaplarını açıklamak ya da düşüncelerini aktarmak için çaba sarf etmiştir. Buna ek olarak tartışmada öğretmen iletişimsel sorularla sıklıkla alternatif söylemleri arama yoluna girmiştir. "Başka, karın oluşumu hakkında fikri olan var mı?" gibi. Alternatif söylemleri arama alt kategorisinin tercihindeki fazlalığın sebebi öğretmenin tartışmanın devamlıı̆̆ı için uygun cevaplara (bilimsel ya da etkinlik bağlamında) ulaşamamış olması olabilir. Kısacası etkinlikte öğretmen vaktinin önemli bir kısmını öğrenenlerin söylemlerini anlama, açıklaştırma ve derinleştirme gibi hamlelerle sağlıkı iletişim kurmaya harcamıştır.
Uygulamada yaşanan bu durum Vygotsky'nin (1987) sosyal dil olgusuyla açıklanabilir (Bakhtin, 1984). Vygotsky dilsel sistemlerin çeşitli düşünsel sistemlerle yakından ilişkili olduğunu savunmuştur (John-Steiner ve Mahn, 1996, Soysal, 2020). Vygotsky'e göre bilgiyi kişiler kendi perspektiflerince alırlar, bu nedenle her bireyin bilgiyi anlamlandırması özgün ve farklı olmaktadır. Bu anlamlandırma süreci ise Vygotsky tarafından iki olgu ile açıklanmıştır. Bunlar "spontane kavramlar" ve "bilimsel kavramlar". Spontane kavramlarda kişi bilgiyi informal biçimde dolaylı olarak kendisi edinir (Soysal, 2019). Ancak bilimsel kavramlar öğrenenlerle kasıtlı olarak bir öğretim eşliğinde yapılandırıır ki bu da okulda aldığımız formal becerileri içermektedir. Örneğin; Su Damlacıklarının Hikayeleri (Maddenin Halleri) adlı uygulamada öğretmen çocuklara karın nasıl oluştuğunu sormuştur. Öğrenenler bu soruya "Kar yağması için böyle bulutun içinde küçük küçük tanelerin olması gerek.", "Küçük küçük şeyler var. Oda buluttur sonra havuzda şeyleri çekiyor biraz." gibi bilimsel olarak tam ifade edilemeyen ancak doğruluk derecesi belirli bir noktaya kadar olan söylemler sunmuştur. Bunun üzerine öğretmen öğrenenlerin bilgilerini bilimsel bir bağlama çekebilmek için derinleştirme "Peki, bulutun içine o küçük taneler nasıl giriyor olabilir?", açıklama isteme "Havuzdaki suları yukarı bulutların çektiğini mi söylemek istiyorsun?" gibi sorulara sıklıkla başvurmuştur. Böylelikle iletişimsel hamlelerin kullanımını (\%52,78 z: 1,58) arttırılabilmiştir. Bir diğer deyişle; çocukların okula getirdiği gündelik ya da günlük acemi sosyal dil ile öğretmenin onlara sunmaya çalıştığı, bilimin diline yakın olan, teknik ve formel dil arasındaki mesafe arttıkça öğretmen çocuklarının söylemlerinin artalanında kalan anlamları netleştirmek için daha fazla iletişimsel soru türevlerini kullanmış olabilir.

"Ağır ve Hafif Taşlar" uygulamasında ise iletişimsel sorular diğer etkinliklere oranla daha az tercih edilmiştir. Uygulamada iletişimsel soruların diğerlerine kıyasla daha az olmasının sebebi olarak uygulamanın konu olarak diğerlerine göre farklılaşan bir bağlamda (deney) incelenmiş olması olabilir. "Ağır ve Hafif Taşlar" fen etkinliği olarak tasarlanmıştır ve süreçte öğrenenlere iletişimsel soruların yanı sıra izleme soruları da fazlaca yöneltilmiştir. Örneğin; "Normalde bu suyun ayıcığı kaldırıp kaldırmadığını görmek istiyoruz. Bakalım kaldırıyor mu?" "İzleme (ileriye)" gibi. Bu durum da öğretmenin deneysel süreçleri gözlemlemek amaçlı "izleme" sorularını sıklıkla kullanabildiği göstermektedir.

Bunun yanı sıra bu uygulamada kullanılan toplam soru türevi sayısı diğer uygulamalara göre daha azdır (Toplam Hamle: 75). Dolayısıyla "iletişimsel" hamlelerinin azlığının sebebi olarak toplam hamle sayısının azlığı da gösterilebilir. Tüm bunlara ek olarak "Ağır ve Hafif Taşlar" uygulaması öğretmenin pilot uygulamalardan sonra sürdürdüğü ikinci uygulamasıdır ve hamle sayısı buna bağlı olarak diğerlerine oranla daha düşük düzeyde seyretmiş olabilir.

Ayrıca iletişimsel soruların azaldığı diğer uygulamalara bakıldığında (ör.,Iki Kafamız Olsa Ne Olurdu? ve Doğal Afetler) diğer soru türevlerinin kullanımı artmış (izleme, değerlendirme, çıkarıma yönlendirme vs.) ve buna bağlı olarak da öğrenenler daha çok "çıkarım" ("Bence etki eder. Çünkü toprağın altından lav çıkarken toprağı ısıtır. Ondan da deprem olabilir." "kanıt gösterme" ("Bence yerin altından çıktı çünkü biz yüksek bir şey çıktığını görmedik.") gibi çeşitli düşünme süreçlerini bir arada kullanabilmiştir. Dolayısıyla iletişimsel sorular bu uygulamalarda daha az tercih edilmiştir ve buna bağlı olarak sorular nispeten daha homojen dağılabilmiştir. 
Tablo 4. Iletişimsel amaçlı soru kategorisine ait gözlemlenen yüzdelik hesaplamalar ve z puanları

\begin{tabular}{lrr}
\hline Uygulama Sırası & Yüzde (\%) & z \\
\hline Su Damlacıklarının Hikayeleri (Maddenin Halleri) & 52,78 & 1,58 \\
\hline Ağır ve Hafif Taşlar & 36,84 & $-1,03$ \\
\hline Mevsimler & 45,50 & 0,38 \\
\hline Dünyamız Nasıl Oluştu? & 42,86 & $-0,04$ \\
\hline Engelli Kimdir? & 39,14 & $-0,65$ \\
\hline Meslekler & 39,95 & $-0,52$ \\
\hline Yaramaz Topların Hikayesi (Yer çekimi) & 46,77 & 0,59 \\
\hline Kış Uykusuna Yatan Hayvanlar & 36,99 & $-1,00$ \\
\hline İki Kafamız Olsa Ne Olurdu? & 49,63 & 1,06 \\
\hline Doğal Afetler & 32,03 & $-1,81$ \\
\hline
\end{tabular}

\section{izleme amaçlı öğretmen soruları}

İleme soruların temel amacı grubun öğretimsel süreçlere ilgisini canlı tutmak ve bilişsel olarak uygulamaya bağlı kalmalarını sağlamaktır. Bu bağlamda öğretmen bu sorularla müzakere edilen konu ile alakalı olarak öğrenenleri sürekli düşünmeye yönlendirmeyi amaçlamıştır. "Bakın arkadaşınız dedi ki; lavlar dışarı çıktığında depreme sebep olabilir". Bunun üzerine konuşalım mı, ne dersiniz?" gibi. Bu amaçla öğretmen izleme sorularını kullanarak müzakerenin şu an nerede olduğunu öğrenenlere sunabilmiştir (Tablo 6, Satır 1-3 ve 9). Örneğin Tablo 6 Satır 1'de öğretmen bilişsel olarak konudan uzaklaşıldığını sezmiş ve öğrenenlere konuya dönmeleri yönünde hatırlatmada bulunmuştur. "Konumuza dönelim ama şimdi. Henüz bir karara ulaşamadık değil mi?". Öğretmen tartışmada bir süre önce veya sonra neler konuşulacağını da izleme sorularıyla sağlamıştır. (ör.; "Bunu daha sonra konuşalım mı?") gibi. Ayrıca bu sorularla tartışma için önemli olduğunu düşündüğü bir cevap üzerine öğrenenlerin yoğunlaşmasına da destek olmuştur. Örneğin; Tablo 6'da uygulamalardan alınmış diyalogda görüldüğü üzere öğrenen gezegenlerin birbirine çarparak depremi oluşturduğunu iddia etmiștir. Başka bir öğrenen ise bu durumun mümkün olamayacağı söylemiş ve öğretmen de önemli olduğunu düşündüğü bu cevaba "odaklama" sorusuyla karşılık vererek "Arkadaşınız yan yana değil çarpışmaz diyor. Bakın farklı fikirler var ne dersiniz?" sorusunu yönelterek çocukları cevap üzerine düşünmeye yönlendirebilmiştir. Buna ek olarak izleme soruları ile öğretmen bazı cevapları öne çıkarırken bazılarını eleyip arka plana atabilmiştir. (ör.; "Bazılarınız lavların depreme etkisi olabileceğini söylüyor. Bence bunu konuşabiliriz ne dersiniz?") gibi. Böylece çocuklar müzakere için önemli iddialar üzerine yeniden düşünülebilmiştir. İleme soruları (meta söylem geliştirme) ile öğretmen öğrenenlerin kendi cevapları üzerine yeniden düşünmesini sağlayabilmiştir. Böylece çocuklar cevaplarının uygunluğunu ya da bilimsel açıdan kabul edilebilirliğini yeniden düşünebilmiş̧lerdir. Örneğin; Tablo 6 Satır 8'de öğrenen konu bağlamından uzakta bir yanıt ile "Baksanıza buradaki gezegenler birbirinden ne kadar uzak!" (Satır 8) tartışmaya katılmak istemiş ancak öğretmen söyleminin konu ile alakasız olduğunu hatırlatarak asıl tartışma konusunu öğrenene "izleme" sorusuyla hatırlatabilmiştir. "Şuan başka bir konuyu tartışıyoruz ama. Sizce meteorlar çarpıştığında deprem olur mu? S5'e katılıyor musunuz?" (Satır 9). Kısacası öğretmen izleme sorularıyla öğrenenlerin zihinlerinin bilişsel olarak tartışma ile ilgili konularla meşgul olup olmadığını kontrol edebilmiştir.
Bu nedenle izleme sorularının kombinasyonlu kullanımı ile öğrenenleri daha üst düzey düşünme süreçlerine yönlendirebilir. Bu durum çalışmada yürütülen tartışmalarda da veri temelli bir biçimde sunulacaktır.

Tablo 5. izleme amaçlı soru kategorisine ait gözlemlenen yüzdelik hesaplamalar ve z puanları

\begin{tabular}{lrr}
\hline Uygulama Sırası & Yüzde (\%) & $z$ \\
\hline Su Damlacıklarının Hikayeleri (Maddenin Halleri) & 5,55 & $-2,18$ \\
\hline Ağır ve Hafif Taşlar & 14,47 & 0,02 \\
\hline Mevsimler & 12,99 & $-0,34$ \\
\hline Dünyamız Nasıı Oluştu? & 15,18 & 0,19 \\
\hline Engelli Kimdir? & 5,99 & $-2,07$ \\
\hline Meslekler & 14,72 & 0,08 \\
\hline Yaramaz Topların Hikayesi (Yer çekimi) & 10,48 & $-0,96$ \\
\hline Kış Uykusuna Yatan Hayvanlar & 16,44 & 0,50 \\
\hline Iki Kafamız Olsa Ne Olurdu? & 11,85 & $-0,62$ \\
\hline Doğal Afetler & 20,91 & 1,61 \\
\hline
\end{tabular}

İzleme sorularının uygulamalardaki kullanımları incelendiğinde tercih oranlarının genel itibariyle benzer seviyelerde seyrettiği görülmektedir. Ancak "Su Damlacıklarının Hikayeleri (Maddenin Halleri)" adlı uygulamada "izleme" sorularının diğer uygulamalara oranla daha az kullanıldığı (\%5.5 z: -2,18) tespit edilmiştir. İzleme sorularının uygulamada az kullanılmasıyla birlikte öğrenenler bilişsel olarak tartışmaya bağlanamamıştır. Yukarıdaki kısımlarda da bahsedildiği üzere öğrenenler izleme hamleleriyle müzakerenin nerede olduğundan, nereye gideceğinden haberdar olmaktadırlar. Bu nedenle izleme sorularının daha az kullanıması "Su Damlacıklarının Hikayeleri (Maddenin Halleri)" adlı uygulamada öğrenenlerin bilişsel olarak "burada" olmamasına sebep olmuştur ve buna bağlı olarak uygulamada çeldirici ve değerlendirici hamleler de azalmış olabilir (Berland ve Hammer, 2012). "iletişimsel" kategoride ayrıntılı açıklandığı üzere bu uygulamada en çok kullanılan sorular derinleştirme, açıklama isteme ve yeniden yapılandırma gibi iletişimsel alt kategorileri içermektedir. Uygulamada öğrenenler daha çok anlaşılmaya çalışıldığından ve bilimsel dil kullanmaya yönlendirildiğinden (Vygotsky, 1987) etkinliği izleme, şu an neler olduğunu-olacağını konuşma gibi sorular geri planda kalmıştır. Dolayısıyla etkinlikte öğrenenler üst bilişsel olarak da takip edilememiştir. Ayrıca çalışmada meta söylem geliştirme sorusuna hiç rastlanmamıştır. Metabilişsel hamleler öğrenenlerin söylemleri üzerine düşünmesini sağlayabilmek ve üst bir söylem geliştirebilmek için önemlidir (Kei ve Wong, 2013). Bu sayede öğrenenler kabul edilebilir olmayan iddialarının (bilimsel bağlamda) takibini kendi sağlayabilir. Böylece öğretmenin sınıftaki mutlak otoritesinin konumu da farklılaşacaktır ve öğrenenler daha fazla değerlendirici roller alabilecektir (Soysal ve Radmard, 2018). Ancak uygulamalar boyunca meta bilişsel hamleler öğretmen tarafından neredeyse hiç $(\% 0,69)$ tercih edilmemiştir. "Şimdi birçok öneri sundun hangisi volkanik dağların patlama sebebi merak ediyorum. Bu olan olaylardan hangisinin depreme etkisi var sence yeniden düşünür müsün?" Bu durum öğrenenlerin tartışmaya bilişsel olarak bağlanamamasında etkili bir diğer değişken olabilir.

Öğretmenin "Doğal Afetler" adlı uygulamada "izleme" hamlelerini diğer soru türevlerine oranla daha fazla (\%20,91 z: 
Tablo 6. Öğretmen Soruların Türevleri ve Alt Türevleri

\begin{tabular}{|c|c|c|c|c|}
\hline $\begin{array}{l}\text { Konuşma } \\
\text { sırası }\end{array}$ & Konuşmacı & Söylem & Öğretmen sorusunun türevi & Kısa açıklama \\
\hline 1. & $\mathrm{~T}$ & $\begin{array}{l}\text { Konumuza dönelim ama şimdi. Henüz bir karara ulaşamadık } \\
\text { değil mi? // Arkadaşınız diyor ki şimşek lavları ısıtır ve vol- } \\
\text { kanik dağ patlar. Diğeri de sesten dolayı patlar diyor. S daha } \\
\text { önce de lavlar yüzünden patlar demişti değil mi? // Şimdi } \\
\text { hangisi volkanik dağların patlama sebebi merak ediyorum. } \\
\text { Bu olan olayların depreme etkisi var mı? }\end{array}$ & $\begin{array}{l}\text { İzleme-anlık// İleme-öze- } \\
\text { tleme// Meta-söylem } \\
\text { geliştirme }\end{array}$ & $\begin{array}{l}\text { Öğretmen o anda neler } \\
\text { konuşulduğunu hatırlatıyor. } \\
\text { // Verilen cevapları özetliyor. } \\
\text { // Öğrenenlerin düšünceleri } \\
\text { üzerine yeniden düşünmesini } \\
\text { istiyor. }\end{array}$ \\
\hline 2. & S1 & Gezegenler birbirine çarpışır ve deprem olur. & - & - \\
\hline 3. & $\mathrm{~T}$ & $\begin{array}{l}\text { Bakın bu da başka bir bakış açısı hangisi doğru şimdi kafam } \\
\text { karıştı bana yardımcı olur musunuz? }\end{array}$ & İzleme-anlık & $\begin{array}{l}\text { Öğretmen o anda neler } \\
\text { konuşulduğunu hatırlatıyor. }\end{array}$ \\
\hline 4. & S2 & Gezegenler yan yana değil ki. & - & - \\
\hline 5. & $\mathrm{~T}$ & $\begin{array}{l}\text { Arkadaşınız yan yana değil çarpışmaz diyor. Bakın farklı } \\
\text { fikirler var ne dersiniz? }\end{array}$ & Odaklama & $\begin{array}{l}\text { Öğretmen öğrenenlerin dikkati- } \\
\text { ni belirli bir cevaba çekiyor. }\end{array}$ \\
\hline 6. & S3 & $\begin{array}{l}\text { Göktaşı çarptığında yanardağ patlar sonra kayalar birbirine } \\
\text { çarpar ve meteorlar çarpar ve yanardağ patlar. }\end{array}$ & - & - \\
\hline 7. & $\mathrm{~T}$ & Meteorlar birbirine çarptığında mı yanardağ patlar? & İletişimsel-açıklama isteme & - \\
\hline 8. & S4 & Baksanıza buradaki gezegenler birbirinden ne kadar uzak. & - & - \\
\hline 9. & $\mathrm{~T}$ & $\begin{array}{l}\text { Şu an başka bir konuyu tartışıyoruz ama şu an. Sizce mete- } \\
\text { orlar çarpıştığında deprem olur mu? S5'e katılıyor musunuz? }\end{array}$ & $\begin{array}{l}\text { İzleme (anlık)// Değer- } \\
\text { lendirme- öğrenci söylemi }\end{array}$ & $\begin{array}{l}\text {-// Öğrencinin verdiği cevabın } \\
\text { diğer öğrenenlerce değerlendi- } \\
\text { rilmesini istiyor. }\end{array}$ \\
\hline 10. & S5 & Öğretmenim bazı gezegenler yan yana bazıları değil. & - & - \\
\hline 11. & $\mathrm{~T}$ & $\begin{array}{l}\text { Depremin sebebi bu mudur? Gezegenler mi birbirine çar- } \\
\text { par? // Ne dersiniz arkadaşınıza katılıyor musunuz? }\end{array}$ & $\begin{array}{l}\text { İletişimsel-açıklama } \\
\text { isteme// Değerlendirme } \\
\text { öğrenci söylemi }\end{array}$ & - \\
\hline 12. & S6 & Ben katılıyorum. & - & - \\
\hline 13. & $\mathrm{~T}$ & O zaman açıklar mısın bize? & İletişimsel-açıklama isteme & \\
\hline 14. & S6 & (Cevap yok). & - & \\
\hline 15. & S5 & $\begin{array}{l}\text { Güneş sistemi volkanik dağ olduğu için lavları ısıtır ve vol- } \\
\text { kanik dağ patlar. }\end{array}$ & - & - \\
\hline 16. & $\mathrm{~T}$ & $\begin{array}{l}\text { Lavlar yerin üstünde değil ama altında onu nasıl ısıtacak? } \\
\text { // Günessin onları ısıtacak kadar ısınması dünyamıza zarar } \\
\text { verebilir mi? }\end{array}$ & $\begin{array}{l}\text { Çeldirme (şeytanın avukatı) } \\
\text { // Göz-Kar-Tah (Tahmin) }\end{array}$ & $\begin{array}{l}\text { Öğrencinin verdiği cevap } \\
\text { içerisindeki çelişki açığa } \\
\text { çıkarılıyor. // Ögrenenlerden } \\
\text { basit tahminler yapması talep } \\
\text { ediliyor. }\end{array}$ \\
\hline 17. & S5 & Biz ölebiliriz. & - & - \\
\hline 18. & $\mathrm{~T}$ & $\begin{array}{l}\text { Değil mi? Evet. O zaman volkanik dağların patlama sebebi } \\
\text { güneş midir? // Şöyle düşünelim eğer volkanik dağları } \\
\text { güneş ısıtsaydı çevresinde ağaçlar ve canlılar yetişmezdi } \\
\text { sıcaklık çok yüksek olurdu ama canlılar var değil mi? // Buna } \\
\text { ne dersin? }\end{array}$ & $\begin{array}{l}\text { Iletiş̧imsel-açıklama } \\
\text { isteme// Çeldirme (şeytanın } \\
\text { avukatı) // Değerlendirme } \\
\text { (öğretmen söylemi) }\end{array}$ & $\begin{array}{l}\text {-//-//Öğretmen sağladığı bir } \\
\text { olayın öğrenenlerce değer- } \\
\text { lendirilmesini talep ediyor. }\end{array}$ \\
\hline 19. & S7 & Çok yüksek ısıda ağaç yaşamaz ki. & - & - \\
\hline 20. & $\mathrm{~T}$ & Değil mi? Ama yaşadığını görüyoruz. & Çeldirme (şeytanın avukatı) & - \\
\hline 21. & S6 & Ama deniz canlıları da vardır. & - & - \\
\hline 22. & $\mathrm{~T}$ & $\begin{array}{l}\text { Şu an başka bir konuyu tartışıyoruz ama. Şimdi arkadaşınız } \\
\text { güneş ısısının volkanik dağları patlattığını savunuyor. Bunu } \\
\text { tartışalım mı? // Öyle olsaydı güneşe çok yakın gezegen- } \\
\text { lerde hayat olurdu. // O kadar yüksek sıcaklıkta yaşayabilir } \\
\text { miyiz? }\end{array}$ & $\begin{array}{l}\text { İzleme (anlık)// Çeldirme } \\
\text { (şeytanın avukatı) // Göz- } \\
\text { Kar-Tah (Tahmin) }\end{array}$ & \\
\hline 23. & $\mathrm{~S}$ & Hayır. & - & - \\
\hline 24. & $\mathrm{~T}$ & Güneşe çok yakın gezegenlerde hayat yok çocuklar. & Kod dışı söylem & - \\
\hline 25. & $\mathrm{~S}_{4}$ & Hiç canlı yok mu orada? & - & - \\
\hline
\end{tabular}

Evet, ama șu an konumuz gezegenler değil. Konumuza geri dönelim mi? Gezegenler deprem olmasına etki eder mi ve güneş volkanik dağları patlatır mı bunu merak ediyorum. 26. $\quad \mathrm{T} \quad$ Aslında S2 en başında söylemişti. "Lavların yerin altında hareket etmesi sonucu dışarı çıkar ve patlamalar olur. Bu lavlar dışarı çıkarken bazı hareketlenmeler olur" demişti.

izleme (anlık)// İzleme (geriye)
-// Öğretmen derste belirli bir süre önce neler konuşulduğunu hatırlatıyor. 
Tablo 6 (Devamı). Öğretmen Soruların Türevleri ve Alt Türevleri

\begin{tabular}{|c|c|c|c|c|}
\hline 27. & $\mathrm{~T}$ & $\begin{array}{l}\text { Şimdi S demişti ki lavlar yerin altında ısınır ve taşları hareket } \\
\text { ettirir. Ve daha önce de yerin üstünde çok ağır bir şey } \\
\text { zıpladığında taşlar hareket eder ve deprem olur. // Siz } \\
\text { hangisine katılıyorsunuz? }\end{array}$ & $\begin{array}{l}\text { İzleme-geriye //Değer- } \\
\text { lendirme-öğrenci söylemi }\end{array}$ & $\begin{array}{l}\text { Öğretmen belirli bir süre önce } \\
\text { konuşulanlar ile ilgili hatırla- } \\
\text { tma yapıyor. // Birbirlerinin } \\
\text { söylediklerinin öğrenenlerce } \\
\text { değerlendirmelerini istiyor. }\end{array}$ \\
\hline 28. & $\mathrm{~S}$ & İkisinde de oluyor bence. & - & - \\
\hline 29. & $\mathrm{~T}$ & İkisinde de olabilir bence dedi, katılıyor musunuz? & $\begin{array}{l}\text { Değerlendirme-öğrenci } \\
\text { söylemi }\end{array}$ & $\begin{array}{l}\text { Birbirlerinin söylediklerinin } \\
\text { öğrenenlerce değerlendirme- } \\
\text { sini istiyor. }\end{array}$ \\
\hline 30. & S1 & Katılıyorum. & - & - \\
\hline 31. & $\mathrm{~T}$ & $\begin{array}{l}\text { İkisinde de deprem olabilir mi? O zaman deprem hem yerin } \\
\text { altında hareket eden sıcak bir tabakadan da olabilir. Hem } \\
\text { yerin üzerinde hareket eden ağır bir nesneden de olabilir, } \\
\text { öyle mi? }\end{array}$ & Açıklama isteme & - \\
\hline 32. & $\mathrm{~S}_{1}$ & Evet. & - & - \\
\hline 33. & $\mathrm{~T}$ & $\begin{array}{l}\text { O zaman biz geçen gün bir deprem yaşadık. Çok büyük bir } \\
\text { hareketlenme mi oldu yeryüzünde peki? }\end{array}$ & Çeldirme-şeytanın avukatı & $\begin{array}{l}\text { Öğrenenin cevabı içerisindeki } \\
\text { çelişkiyi ortaya çıkarıyor. }\end{array}$ \\
\hline 34. & S2 & Hayır. & - & \\
\hline 35. & $\mathrm{~T}$ & Çok ağır bir şey mi hareket etmişti sizce? & Göz-Kar-Tah/Tahmin & $\begin{array}{l}\text { Öğrenenlerin basit tahminlerde } \\
\text { bulunmasını istiyor. }\end{array}$ \\
\hline 36. & S3 & $\begin{array}{l}\text { Bence yerin altından çıktı çünkü biz yüksek bir şey çıktığını } \\
\text { görmedik. }\end{array}$ & - & - \\
\hline 37. & $\mathrm{~T}$ & $\begin{array}{l}\text { O zaman yerin üzerinde olan şeyler depremi etkilemiyor } \\
\text { öyle mi S, fikrini mi değiştirdin? }\end{array}$ & $\begin{array}{l}\text { İzleme-fikir değişimini test } \\
\text { etme }\end{array}$ & $\begin{array}{l}\text { Öğrenenleri fikrinin değişip } \\
\text { değişmediği hakkında düşün- } \\
\text { meye yönlendiriyor. }\end{array}$ \\
\hline
\end{tabular}

1,61) tercih ettiği görülmektedir. İzleme hamleleriyle öğretmen gruba tartışmanın bilişsel boyutu ile ilgili destek verebilmiştir. Örneğin; odaklama hamlesiyle "Bakın arkadaşınız dinozorların depreme sebep olduğunu söylüyor. Ne dersiniz buna?" öğrenenleri tartışmaya uygun gördüğü (bilimsel ya da hedeflenen kazanımlar açısından) bir boyuta çekebilmiştir. Öğrenenler bu söylemle birlikte arkadaşının iddiası bilişsel süzgecinden geçirebilmiş ve sonucunda "Öğretmenim dinozorlar öldü sadece kemikleri kaldı. Ama hala deprem oluyor." yanıtıyla arkadaşının tezini çürütebilmiştir. Burada veri temelli biçimde izleme hamlelerin kombinasyonlu kullanımının tartışmaya olan üst düzey bilişsel katkısını göstermektedir (Berland ve Hammer, 2012, Ford, 2008; Soysal, 2019). Bununla birlikte uygulamada "çeldirme" soruları da "izleme" sorularına paralel olarak artış göstermiştir. Bu da soruların diğer uygulamalara kıyasla daha homojen dağıımına katkı sağlamıștır. Tüm bunlara ek olarak izleme hamlelerinin diğer kategorilere oranla daha fazla tercih edildiği uygulamalarda çeldirme ve değerlendirme sorularının da artmış olması bilişsel olarak daha bağlı olunan ve tartışmanın takibi sağlanan uygulamalarda değerlendirmelerin ve çeldirmelerin daha fazla kullanılabildiğini veri temelli olarak gösterebilmiştir (Soysal, 2019).

\section{Değerlendirme amaçlı öğretmen soruları}

Öğretmen bu kategorideki sorular ile öğrenenlerin söylemlerini, kendi söylemlerini ya da müzakere esnasında oluşan bir durumun, olayın ya da iddianın öğrenenler tarafından değerlendirilmesini talep etmektedir. Tablo 3'te görüldüğü gibi değerlendirme soruları üç farklı alt kategori içermektedir. Değerlendirme amaçlı öğretmen soruları ile öğrenenler değerlendirme/eleştirme süreçlerine açıkça davet edilebilmiştir. Böylece öğrenenler sunulan iddiaların doğruluğuna ve yanlışlığına karar verme fırsatı yakalamış ayrıca söylemle- rin tartışmaya uygun olup olmadığına karar verebilmiştir. Bir başka söylemle değerlendirici soruların varlığıyla öğrenenler sunulan iddiaların eleștirme ve yargılama süreçlerine girmișlerdir. Bu sayede gruptaki bilişsel etkileşimler arttırılabilmiştir. Ayrıca öğrenenler arasındaki fikir alışverişi desteklenerek öğrenenlerin tartışmaya katkısı arttırılabilmiş ve böylece sınıf-içi müzakereler zaman zaman öğrenci-öğrenci şeklinde ilerleyebilmiştir. Tablo 6'da "Doğal Afetler" konulu diyalogda öğrenenler deprem olgusunun sebebine atıf yapan iddialar "Lavlar yerin altında ısınır ve taşları hareket ettirir. Yerin üstünde çok ağır bir şey zıpladığında taşlar hareket eder ve deprem olur." ortaya atmaktadırlar. Öğretmen ise bu iddiaları değerlendirmesi için gruba sunmuştur (Satır 27). Ayrıca öğretmen değerlendirici sorular ile kendi söylemlerinin de öğrenenlerce değerlendirilmesini istemiştir. Bu kategorideki sorular ile sınıf içerisindeki tek otorite tarafından süreç yönetilmemiş olup makul bir açıklaması olan herkesin söylemleri, iddiaları tartışılıp değerlendirebilmiştir. Bu da tüm grup üyelerinin hem sürece bağlı̆ğını arttırmış hem de delil temelli iddialar sunmaya yönlendirmiştir. Tablo 6 Satır 18'de görüldüğü gibi güneşin volkanik dağları ısıtarak patlamasına sebep olduğunu iddia eden bir öğrenene karşılı öğretmen bir iddia sunmuş ve bu iddianın diğer grup üyelerince değerlendirilmesini talep etmiştir. Ayrıca bu kategorideki sorular ile tartışma esnasında ortaya çıkan bir durumun da grup tarafından değerlendirilmesi talep edilmiştir. Böylece grubun fikir birliğine vardığı söylemler tespit edilebilmiştir. (ör.; "Şimdi biz buharlaşan suların yağmur olarak geri geldiğini söylüyoruz o zaman. Herkes buna katılıyor mu?") gibi. Bu sorular ile öğrenenlerin tartışmaya olan bilişsel katkıları arttırılabilir çünkü öğrenenler bu sorular eşliğinde değerlendirme ölçütleri oluşturma, diğerlerinin fikirlerini analiz etme, eleştirme, yargılama ve çürütme gibi süreçlere girebilir. 
Tablo 7. Değerlendirme amaçlı soru kategorisine ait gözlemlenen yüzdelik hesaplamalar ve z puanları

\begin{tabular}{lcc}
\hline Su Damlacıklarının Hikayeleri (Maddenin Halleri) & 5,55 & $-0,71$ \\
\hline Ağır ve Hafif Taşlar & 2,63 & $-1,40$ \\
\hline Mevsimler & 9,10 & 0,12 \\
\hline Dünyamız Nasıl Oluştu? & 3,57 & $-1,18$ \\
\hline Engelli Kimdir? & 5,98 & $-0,61$ \\
\hline Meslekler & 7,97 & $-0,14$ \\
\hline Yaramaz Topların Hikayesi (Yer çekimi) & 5,64 & $-0,69$ \\
\hline Kış Uykusuna Yatan Hayvanlar & 6,85 & $-0,40$ \\
\hline Iki Kafamız Olsa Ne Olurdu? & 5,18 & $-0,80$ \\
\hline Doğal Afetler & 15,69 & 1,68 \\
\hline Doğal Afetler & 20,91 & 1,61 \\
\hline
\end{tabular}

Değerlendirme amaçlı öğretmen sorularının kullanımları incelendiğinde en çok tercih edilme oranına sahip uygulamanın "Doğal Afetler" olduğu görülmektedir. Uygulamada değerlendirici soruların daha çok kullanılabilmesinin sebebi tartışmanın doğasının (konusunun) değerlendirme amaçI sorulara yatkın olması olabilir (Kruistum ve van der Veen, 2015). Çünkü temelde bir tartışmanın var olabilmesi konunun karşılıklı konuşmaya müsait ve "tartışılabilir" nitelikte olmasına bağlıdır. Vygotsky (1987) ve Doblaev (1984)'in söylemlerine paralel olarak konuşmanın yeni düşünce sistemlerine bağlanabilmesi için iş birlikli şekilde desteklenmesi ve geliştirilmesi gerekmektedir. Ancak öğretmen tarafından sağlanacak bu destek yalnızca tartışmanın var olabilmesiyle oluşacaktır. Bu nedenle içeriğin daha "tartışılabilir" nitelikte olması konuşmanın bilişsel olarak ilerleyebilmesi açısından oldukça kritik bir öneme sahiptir. Etkinlikte deprem olgusunun temel sebebinin ne olabileceği tartışı ımış ve bunun üzerine grup tarafından çeşitli iddialar ortaya atılmıştır. Öğrenenler doğal afetler için fazlaca örnek verebilmişler bu nedenle tartışma akıcı olarak ilerleyebilmiştir. Bu durumun sebebi olarak tartışmanın güncel bir deprem afetinden sonra yapılandırılması gösterilebilir. Dolayısıyla Vygotsky'nin sosyo-kültürel-tarihsel öğrenme temelli gelişim prensibine göre (1987) grubun belleklerindeki deprem olgusu günceldi ve bireylerin kişisel tarihlerinde deprem olgusu bulunmaktaydı. Böylece sonuç olarak öğrenenler müzakereye bilişsel olarak bağlı kalabilmiştir ve iddiaları belirli kriterler kullanılarak değerlendirebilmiştir. Bununla birlikte öğrenenler daha çok etkileşimde bulunabilmişler ve fikir değişimleri daha çok olabilmiştir (ör., "Ama az önce yerin üstünde bir şey zıplamadığı halde deprem olduğunu söyledin. O zaman fikrini mi değiştirdin?" gibi).. Üretken sınıf diyalogundaki önemli unsurlardan biri de sınıfın fiziksel alanı dışındaki olayları da kontrol edebilmeyi (çok yönlülük) gerektirir (Dobber ve van Oers, 2015). Çünkü tartışmalar sınıfın kültürel perspektifiyle birlikte var olmaktadır ve her bireyin kişisel bir tarihi bulunmaktadır. Bu nedenle etkinlikler yapılandırılırken tarihsel ve kültürel bağlam da göz önünde bulundurulmalıdır.

Bu duruma ek olarak; "Dünyamız Nasıl Oluștu?" adlı uygulamada da değerlendirici sorular oldukça düşük tercih edilme oranına sahiptir (\%3,57 z: -1,18). Etkinlik genel hatlarıyla tanıtılacak olursa öğrenenlerle dünyanın ve kıtaların oluşum süreci müzakere edilmiştir. Etkinlikte değerlendirici soruların diğer kategorilere kıyasla ciddi anlamda az tercih edildiği görülmektedir. En çok kullanılan kategori iletişimsel olmuş $(\% 42,86$ z: -0,04) bunu takip eden ikinci soru türevi ise izleme soruları (\%15,18 z: 0,19) olmuștur. Etkinlik esnasında çocukların dünyayı ve kıtaları anlamlandırabilmesi amacıyla dünya simülasyonu oluşturulmuştur. Ancak öğrenenler bu süreci bulundukları dönem itibariyle anlamlandıramamıştır bu nedenle öğretmen etkinlikte daha çok iletişimsel-bilgiyi arama (hatırlama) sorularını kullanmıştır. "O zaman biz büyük denizlere ne diyoruz?", "Dünya üzerinde kaç tane kıta var biliyor musunuz?"," Peki, dünyamızın soğumayan tek yeri neresiydi?" gibi. Dolayısıyla bu söylemlerden değerlendirme sorularının az kullanılmasının sebebi olarak sunulacak sonuç tartışmanın konusunun öğrenenler için soyut kalması olabilir. Bu nedenle öğretmen daha çok iletişimsel-derinleştirme sorularıyla "İşte neden oluşmuştur yer küre? Dünya nasıl oluşmuştur bir düşünün bakalım?" gibi hamlelerle öğrenenleri düşünmeye yönlendirmiş ya da izleme-anlık sorularıyla "Evet, sonbahar mevsimindeyiz ama konuştuğumuz konu o değil. Biz şu an dünya ile ilgili konuşuyoruz" konu bağlamını tartışmaya davet eden hamleleri sıklıkla kullanmak durumunda kalmıştır.

Üretken sınıf konuşmalarının yaratılabilmesi için temel odak noktalarından biri de "yaratıcı düşünme alanları" oluşturabilmektir (Wegerif, 2008). Böylece öğrenenlere odaklanılan konu ile ilişkili olarak yansıma durumları yaratılabilir. Bu da tartışmaya daha derin bağlanmalarına yardımcı olabileceği gibi yeni anlamlar ve tahminler de ortaya çıkarabilecektir. Etkinlikte bu durum göz önünde bulundurularak dünyamız somutlaştırılmaya çalışılmış ancak öğrenenler bulunduğu dönem itibariyle yine de tartışmaya bilişsel olarak bağlanamamıştır. Bu durum öğrenenlerin ortaya attığı "Denizde zaten az su olan taraflarda bir sürü taş var. O taşlar denizin altına gidince orada sudan ve havadan büyüyor sonra yanardağ oluyor.", "Su ile taşların arasında böyle minik delikler var onlar içine girip böyle taşlar büyüyor." gibi iddialardan net bir şekilde anlaşılabilmektedir.

"Ağır ve Hafif Taşlar" uygulamasındaki değerlendirici soruların oldukça az olması da dikkat çekmektedir. Etkinlikte öğretmen öğrenenlerden taşların ağırlıkları hakkında fikir yürütmelerini talep etmiş ve öğrenenler terazi ile taşların ağırlıklarının ölçülebileceği ya da suyun içine atıldığındaki konumlarına bağlı olarak tespit edileceği sonuçlarına ulaşabilmiştir. Bu nedenle müzakere esnasında daha çok iletişimsel-izleme hamleleri sıklıkla tercih edilmiştir. Çünkü deneylerin sürdürülebilmesi için şuan burada neler olduğunu ve neler olacağını öğrenenler ile paylaşmak gerekmektedir. Bu durum diğer soruların az kullanılmasına sebep olmuş olabilir. Buna bağlı olarak öğrenenler tartışmaya bilişsel olarak bağlanmaktan ve iddialar üzerine tartışmaktan ziyade taşların ağırlıklarının ölçümüne ve teraziye odaklanmışlardır. Tüm bu durumların kontrolü ise iletişimsel ya da izleme sorularıyla sağlanabilmiştir "Bir deneyelim mi? Iki tane hafif nesneyle, iki tane aynı ağırıktaki nesneyi suya atacağım. Bakalım ne olacak?" gibi.

\section{Çeldirme amaçlı öğretmen soruları}

Bu kategorideki sorular ile öğretmen öğrenenlerin sağladığı cevaplar içerisine gömülmüş olan epistemolojik, ontolojik ve kavramsal çelişkileri ortaya çıkarmayı amaçlamıştır. Tablo 3'te de görüldügüü üzere çeldirme soruları sınıf-içi uygulamalarda iki farklı alt kategoride işe vuruklaştırılmıştır. Öğretmen "çeldirme" soruları ile öğrenenlerin iddialarının ya da söylemlerinin içerdiği çelişskileri ortaya çıkarmıştır. Tablo 6'da "Doğal Afetler" uygulamasından bir kesit görülmektedir. Burada güneşin lavları ısıtığını iddia eden öğrenenin cevabı (Satır 15) öğretmen tarafından çeldirilmiş ve cevabın içerdiği çelişkiler 
bakımından irdelenmiştir (Satır 16). Tablo 3'te depremin yerin üzerinde ağır bir nesnenin zıplamasıyla oluştuğunu iddia eden bir öğrenenin cevabı içerisindeki çelişki öğretmen tarafından ortaya çıkarılmıştır. Örneklerde görüldüğü üzere öğretmen şeytanın avukatı rolüyle öğrenenlerin cevapları içerisindeki çelişkileri ortaya çıkarıp iddiaları delillendirerek çürütmüştür. Çeldirme soruları buna ek olarak öğrenenlerin cevaplarının iç tutarııı̆ını da sorgulamıştır. Örneğin; "Ama bu hayvanlar hiç uyanmıyorlar ki! Uyanmadıkları için o yiyecekleri yiyebilirler mi?" Burada öğretmen izleme ile öğrenenlerin cevaplarının iç tutarlıığı olmadığını açığa çıkarabilmiştir.

Tablo 8. Çeldirme amaçlı soru kategorisine ait gözlemlenen yüzdelik hesaplamalar ve z puanları

\begin{tabular}{lrc}
\hline Uygulama Sırası & Yüzde (\%) & z puanı \\
\hline Su Damlacıklarının Hikayeleri (Maddenin Halleri) & 1,39 & $-1,97$ \\
\hline Ağır ve Hafif Taşlar & 5,26 & $-0,24$ \\
\hline Mevsimler & 2,60 & $-1,43$ \\
\hline Dünyamız Nasıı Oluştu? & 2,68 & $-1,39$ \\
\hline Engelli Kimdir? & 5,14 & $-0,30$ \\
\hline Meslekler & 4,29 & $-0,68$ \\
\hline Yaramaz Topların Hikayesi (Yer çekimi) & 2,42 & $-1,51$ \\
\hline Kış Uykusuna Yatan Hayvanlar & 6,16 & 0,15 \\
\hline İki Kafamız Olsa Ne Olurdu? & 8,15 & 1,04 \\
\hline Doğal Afetler & 8,50 & 1,19 \\
\hline
\end{tabular}

Çeldirme amaçlı soruların uygulamalardaki kullanımları incelendiğinde belirli bir dereceye kadar artan bir eğilimin olduğu görülebilir. Örneğin öğretmen ilk uygulaması olan Su Damlacıklarının Hikayeleri (Maddenin Halleri) uygulamasında bu oran \%1,39 ( $z$ : -1,97) iken "Doğal Afetler" uygulamasında \%8,50'e (z: 1,19) yükselebiliştir. Uygulamalar ilerledikçe öğrenenlerin ve öğretmenin tartışma süreçlerine alışmış olması ya da konuların müzakereye yatkınlığı da çeldirici hamlelerin artmasında etkili olmuş olabilir. Bunun yanında öğrenenleri bilişsel olarak ikilemde bırakan uygulamalarda çeldirici sorular daha fazla kullanılabilmiştir (ör., "Iki Kafamı Olsa Ne Olurdu?" \%8,15 z: 1,14).

"Dünyamız Nasıl Oluştu?" adlı uygulama incelendiğinde çeldirici soruların diğer uygulamalara oranla daha az tercih edildiği görülmektedir. Bu uygulamada dünyanın ve kıtaların oluşum sürecine atıflar yapıımış ve kıtaların nasıl oluşmuş olabileceği tartışma konusu olmuştur. Konu çocuklar için fazla soyut olduğundan müzakereye eğilim az olmuş ve tartışma daha çok söylemleri anlama, açıklama ya da öğretmen tarafından bakılacak olursa cevapları kabul etme ya da reddetme șeklinde ilerlemiștir. Örneğin; tartıșmada bir öğrenen denize atılan taşlardan kıtaların olușabileceğini iddia etmiş bunun üzerine öğretmen öğrenenin söylemini tartışmaya açmış ve arkadaşlarından değerlendirmesini talep etmiştir. Karşılık olarak bir öğrenen "Ben katılmıyorum. Bütün çocuklar denize taş atıyor. Bütün çocuklar denize taş atarsa eğer bir sürü kıta olmuş olur." diyerek bu söylemi çürütebilmiş fakat öğretmen "Peki, sence kıtalar nasıl oluşmuş olabilir?" sorusunu yönelttiğinde "Bilmiyorum ki" cevabıyla delil temelli yeni bir iddia üretememiştir. Benzer durum "Yaramaz Topların Hikayesi (Yer çekimi)" adlı uygulama için de geçerli olabilir. Her ne kadar üretken sınıf söylemi ile çeldirici sorular arasında ciddi bir ilişki olsa da öğretmen belli başlı uygulamalarda bu tipte soruları icra edememişlerdir. Bunun en önemli sos- yo-dilbilimsel sebeplerinden biri van der Veen, Kruistum ve Micheals'ın (2015) da belirttiği üzere müzakereye ya da tartışmaya tabi olan konular öğrenenlerin ilgisini çekmeli, onlar söylemsel süreçlere bilişsel olarak bağlanabilmeli (Engle ve Conant, 2002), entelektüel katkı sağlama noktasında üretken olabilmeli, kısaca konular grubun sembolik düşünme ve akıl yürütme düzeyinin ötesinde olmamalıdır. Kıtaların oluşumu mikro, makro ve sembolik kavramsal dünyaların karşılıklı bir şekilde etkileştirilmesini ve tektonik hareketler, kıta hareketleri vs. gibi üst düzey soyutlamalar ya da sembolik usavurumlar yapılmasını gerektiren bir konu içeriği olarak düşünülebilir. Dolayısıyla bu konu içeriği ya da bağlamı öğretmene sınıf içi müzakereyi derinleştirmek için çeşitli söylemsel fırsatlar sağlayamamış olabilir. Bu ise öğretmenin daha az çeldirici soru yöneltmesine sebep olmuş olabilir.

Ancak öğretmen "Iki Kafamız Olsa Ne Olurdu?" adlı uygulamada çeldirici sorular diğerlerine kıyasla ciddi oranda kullanılabilmiştir. Bu uygulamada çeldirici sorulara daha sık rastlanabilmesinin sebebi olarak; öğrenenlerin duruma sosyal-duygusal açıdan birçok iddia sunabilmesi etkili olmuş olabilir. Örneğin; "iki kafalı olan kișilerle arkadaş olur musunuz?" bağlamının müzakere edildiği sırada "Kötü insanları nasıl tespit edebiliriz?" sorusuna bir öğrenen "Sesinden anlayabiliriz. Sesi kalın olanlar kötüdür." yanıtını vermiş ve bunun üzerine öğretmen çeldirme hamlesiyle "O zaman sesi kalın insanlar kötü müdür? Çünkü S3'ünde sesi kalın ama çok iyi bir arkadaşımız değil mi?" diyerek alternatifli bir akıl durumu öğrenenlere sunabilmiştir. Bahsi geçen uygulamada çocukların çeşitli argümanlar üretebildiği, bunların çeşitli bilişsel anlamda kavramsal, epistemolojik ve ontolojik çelişkiler taşıdığı, bunların ise alternatif akıl yürütme önerileriyle öğretmen tarafından maddileştirildiği ya da yanlışlandığı gözlemlenmiştir. Başka bir deyiş̧le, çeldirici soruların sınıf içinde görülebilmesinin önemli şartlarından biri öğrenenlerin o konuya yönelik müzakere ortamına dahil olabilecek bir art alan kavramlar dizisine sahip olmasıdır (Kiemer, Gröschner, Pehmer ve Seidel, 2015).

Çeldirici soruların fazlaca gözlemlendiği uygulamalardan biri de "Doğal Afetler" uygulamasıdır. Öğrenenler bu uygulamada çokça iddia ortaya atabilmiştir. Fakat ortaya atılan bu iddialardaki akı yürütmeler çoğunlukla hatalı ya da bilimsel olgularla çelişen durumlar içermektedir. Bu nedenle öğretmen iddiaların içerisindeki ontolojik, epistemolojik ya da kavramsal çelişkileri ortaya çıkarabilmek amacıyla öğrenenlere çeldirici hamlelerle meydan okumuştur. Örneğin; öğretmen öğrenenlerden "Sizce depremin oluşmasına sebep olan nedir?" sorusuna oldukça yaratıcı fakat olgusallıktan uzak yanıtlar almıştır. Örneğin;

Öğrenen-1: "Yerin altındaki taşlar kıpırdayınca yerde hareket ediyor o zaman deprem olmuş oluyor. Ağır bir şey zıplarsa o zaman olabilir.",

Öğrenen-2: "Dinozorlar yere güm güm vurunca yer sarsıntısı ve deprem oluşur.",

Öğrenen-3: "Gezegendeki taşlar birbirine çarpar ve deprem oluşur." gibi.

Ancak öğretmen cevapların çoğuna çeldirici hamleler ile karşılık vermiştir. Örneğin öğretmen "Günümüzde dinozorlar yok ama hala deprem oluyor. Buna ne dersin?" gibi söylemlerle öğrenenleri müzakere konusu üzerinde yeniden düşünmeye yönlendirmiştir. Öğretmen çeldirici sorularını 
sıklıkla kullanmaya başladığında, öğrenenlerin diyalog zeminini kaydırarak üzerlerindeki bilişsel yükten kurtulmaya çalışmaktadır. Çünkü öğretmen çeldirici hamlelerle öğrenenlerin kısa süreli belleğini (working memory) fazlaca meşgul etmiş, dolayısıyla öğrenenler depremi daha keyfi söylemlerle ya da "çocukların bilimi" (Vosniadou, 1994; Vosniadou ve Brewer, 1992) ile açıklamaya çalışmışlardır (Chandler ve Sweller, 1991; Sweller, 1988). Esasında depremler ya da doğal afetler konusunun öğretmene daha çok çeldirici soru sorma yöneltme şansı verdiği gözlemlenmiştir. Öğretmen çocukları çeldirici sorular aracılığıyla bilişsel olarak zorlayıp, yükledikçe, çocuklar bir bilişsel dengesizlik ya da tatminsizlik yaşamış olabilirler (Piaget, 1997). Esasında Piaget (1997) bilişsel dengesizlik ya da tatminkâr ol(a)mama anlarının kavram inşa etme ya da genişletme için en önemli anlardan biri olduğunu ifade etmiştir. Ancak iyi bilindiği üzere, çocuklar genellikle ciddi ve geri döndürülemez karşı argümanların, ki bu çalışmada öğretmenin çeldirici soruları ile belirginleştirilmiştir, varlığında ya da rahatsızığında dahi ön-kavramlarını ya da bilimin sosyal dilinden uzak olan günlük algılarını koruma ya da değiştirmeme eğilimindedirler (Piaget, 1997). Depremler ve diğer doğal afetler konularının tematik ya da kavramsal içeriği sınıf içi derin müzakerelere izin verse de ya da öğrencilerin kavramsal bir hoşnutsuzluk yaşasalar da, yukarıdaki metafizik diyalogda da görüldüğü üzere, çocuklar "ad hoc" hipotezler üretmekten geri dur(a)mamışlardır. "Ad hoc" hipotezler bilim dünyasında ya da tarihinde de mevcuttur ve sunulan herhangi bir çelişkiyi var olan bilgi şemalarının ya da modellerinin içine keyfi bir şekilde yerleştirmeye ve pragmatik bir şekilde bunları, eski ve çelişen yeni bilgiyi, birlikte kullanma alışkanlığıdır. Bu zihinsel alışkanlığın özellikle okul öncesi çocuklarda gözlemlendiği bilinmektedir (Piaget, 1997). Bu çalışma ise öğretmenin tartışmaya ve müzakereye oldukça izin veren bir konuda doğru zamanda ya da bağlamda çeldirici soruları kullanabilmesinin öğrenenlerin var olan günlük, acemi fikirlerinden ayrılıp, onları reddedeceği anlamına gelmediğini delil temelli bir şekilde göstermiştir.

Delillendirme amaçlı öğretmen soruları: Delillendirme amaçlı öğretmen soruları öğrenenlerin iddiaları için yeterli ve uygun miktarda delillerin varlığını sorgulamaktadır. Bu kategorideki öğretmen soruları ile öğrenenlerin deliller sunmaya yönlendirilmesinin yanı sıra akıl yürütmelerinde de delil kullanmaya yönlendirmiştir. Tablo 3'de de görüldüğü gibi tartışmalarda iki alt kategori ile birlikte kullanılmıştır. Bu soru türüyle öğretmen, öğrenenleri söylemlerini destekleyecek bilimsel kabul edilirliği olan deliller göstermesi yönünde desteklemiştir. Örneğin; ("Peki, neden gök gürültüsünün volkanik dağları patlattığını düşünüyorsun? Senin böyle düşünmene sebep olan nedir? Nereden biliyorsun böyle olduğunu?") bu soruda öğretmen volkanik dağ ile gök gürültüsü arasında bağlantı kuran öğrenenin iddiası için uygun delilinin olup olmadığını irdelemektedir. "Kıtaların dünya üzerinde hareket ettiğini nasıl anlarız?" burada da benzer şekilde öğrenenin iddiasının delil temelli olması yönünde bir talepte bulunulmaktadır. "Delillendirme" soruları tartışmaların bilimsel bir bağlamda devam etmesi ve öğrenenlerin bu ortak ağzı kazanması açısından önemlidir.

Delillendirme sorularının uygulamalardaki tercih eğilimleri incelendiğinde oldukça farklı kullanım oranları görülmektedir. Temelde delillendirme sorularının uygulamalar boyunca kullanımı düşük düzeyde seyretmiştir. Hatta bazı uygulamalarda hiç kullanılmamıştır (ör., Ağır ve Hafif Taşlar ve Engelli Kimdir?). Erken çocukluk döneminde öğrenenlerin bilişsel olarak içinde bulunduğu dönem baz alındığında delillendirme soruları iddiaların bir dayanağı olması açısından önemli olabilmektedir. Delillendirme sorularının en çok tercih edildiği uygulama "Su Damlacıklarının Hikayeleri (Maddenin Halleri)" (\%6,94, z: 1,09) olmuştur. Kısacası öğretmen bu uygulamada öğrenenlerden ısrarla iddialarına delil göstermelerini talep etmiştir. Bu durumun sebebi olarak uygulamanın pilot uygulamalardan sonra gerçekleştirilen ilk uygulama olmasının etkisi olduğu düşünülmektedir. Öğrenenler henüz müzakere ile yeni karşılaştığından iddiaları delil temelli olamamıştır. Bu durumda öğretmen öğrenenleri sıklıkla delil temelli konuşmaya yönlendirmiştir. Ancak "iki Kafamız Olsaydı Ne Olurdu?" uygulaması sosyal-duygusal bir etkinlik olarak tasarlandığından delillendirmelerin daha az anlamlı olabileceği söylenebilir. Çünkü yorumlamalar daha bireysel olmuş, bu nedenle bilimsel bir gerçekliğin savunulması zorlaşmıştır. Bunun yanı sıra "Yaramaz Topların Hikayesi (Yer çekimi)" adlı uygulamada delile yönlendirme soruları oldukça az tercih edilmiştir. Oysaki bu uygulamada delillendirme soruları müzakerenin gidişatı açısından kritik olabileceği düşünülmektedir.

Tablo 9. Delillendirme amaçlı soru kategorisine ait gözlemlenen yüzdelik hesaplamalar ve z puanları

\begin{tabular}{lrr}
\hline Uygulama Sırası & Yüzde (\%) & z puanı \\
\hline Su Damlacıklarının Hikayeleri (Maddenin Halleri) & 6,94 & 1,09 \\
\hline Ağır ve Hafif Taşlar & 0 & - \\
\hline Mevsimler & 5,15 & 0,04 \\
\hline Dünyamız Nasıl Oluştu? & 6,25 & 0,69 \\
\hline Engelli Kimdir? & 0 & - \\
\hline Meslekler & 0,61 & $-2,61$ \\
\hline Yaramaz Topların Hikayesi (Yer çekimi) & 2,42 & $-1,55$ \\
\hline Kış Uykusuna Yatan Hayvanlar & 4,12 & $-0,55$ \\
\hline İki Kafamız Olsa Ne Olurdu? & 0,74 & $-2,53$ \\
\hline Doğal Afetler & 3,92 & $-0,67$ \\
\hline
\end{tabular}

\section{Gözlem-karşılaştırma-tahmin amaçlı öğretmen soruları}

Bu kategorideki öğretmen soruları ile öğrenenler günlük gözlemlerini paylaşmışlar; nesne, iddia ve olayları karşılaştırmışlar; ayrıca bir durum ile ilgili basit tahminler (varsayımsal akıl yürütmeler) yapmışlardır. Tablo 3' te de görüldüğü üzere gözlem-karşılaştırma-tahmin amaçlı öğretmen soruları üç alt kategori ile birlikte sınıf içi uygulamalarda kullanıımıştır. Öğretmen "gözlem" soruları ile öğrenenlerden önceki gözlemlerini paylaşmasını talep etmiş ya da sınıf-içi uygulama sırasında bir olayı/nesneyi gözlemlemesini talep etmiştir. Örneğin; ("Şu anda hava nasıl?"). ("Bu arada elinize sürdüğüm margarine dokunarak neler hissettiğinizi düşünür müsünüz?) bu sorularda da benzer biçimde öğretmen deney esnasında çocuklardan gözlemler yapmalarını istemektedir. "Karşılaştırma" soruları ile öğretmen çocuklardan durumları, örnekleri, iddiaları karşılaştırmasını istemektedir. Örneğin; ("Hangi elinizle soğuğu daha çok hissediyorsunuz?") gibi. ("Ayak klrılması bir engel midir?") bu soruda öğretmen öğrenenlerden "engelli durumu" ile "ayak kırılmasını" karşılaştırmalarını ve ayağı kırılan insanların engelli kategorisinde yer alıp alamayacağını belirlemelerini beklemektedir. "Tahmin" soruları ile öğretmen öğrenenlerden bir durum ile ilgili tahminler yapmasını istemektedir. Tablo 6 Satır 16'da öğretmen öğrenenlerden güneşin ısısıyla ilgili varsayımsal bir akıl yürütme yapmalarını istemiştir. Ayrıca Satır 22'de de benzer şekilde "insanların çok yüksek sıcaklıkta yaşayıp yaşayamayacağı" konusunda varsayımsal bir akıl yürütme yapmalarını talep etmektedir. 
Tablo 10. Gözlem-Karşılaştırma-Tahmin amaçlı soru kategorisine ait gözlemlenen yüzdelik hesaplamalar ve z puanları

\begin{tabular}{lrr}
\hline Uygulama Sırası & Yüzde (\%) & z puanı \\
\hline Su Damlacıklarının Hikayeleri (Maddenin Halleri) & 8,34 & $-0,86$ \\
\hline Ağır ve Hafif Taşlar & 11,84 & 0,16 \\
\hline Mevsimler & 3,90 & $-2,18$ \\
\hline Dünyamız Nasıl Oluştu? & 10,71 & $-0,16$ \\
\hline Engelli Kimdir? & 16,38 & 1,51 \\
\hline Meslekler & 7,95 & $-0,98$ \\
\hline Yaramaz Topların Hikayesi (Yer çekimi) & 10,48 & $-0,23$ \\
\hline Kış Uykusuna Yatan Hayvanlar & 13,69 & 0,71 \\
\hline İki Kafamız Olsa Ne Olurdu? & 3,70 & $-2,24$ \\
\hline Doğal Afetler & 11,11 & $-0,04$ \\
\hline
\end{tabular}

Uygulama bazlı olarak gözlem-karşılaştırma-tahmin soruları incelendiğinde çeşitlenen bir yelpazede kullanıldığı görülmektedir. Örneğin; "Mevsimler" ve "Iki Kafamız Olsa Ne Olurdu?" adlı uygulamada kullanımı oldukça düşükken "Engelli Nedir?" adlı uygulamada öğretmen öğrenenleri günlük tecrübelerinden faydalanması için fazlaca teşvik etmiştir. Bu durum engel durumuyla ilgili olarak öğrenenlerin günlük hayatta daha çok gözlem yapabilmesinden kaynaklı olabileceği düşündürmektedir.

\section{Çıkarım amaçlı öğretmen soruları}

Bu kategorideki öğretmen soruları ile grup, tartışılan konudan hareketle bir "çıkarım" yapmaya yönlendirilmektedir. Tablo 3'te de görüldüğü üzere iki alt kategori içermektedir. "Sonuçlandırma" soruları öğrenenlerin yapılan sınıf-içi uygulamadan hareketle bir sonuca varmalarını istediği soru türüdür. Örneğin; ("O zaman her meslek sahibi emekli olur mu?") bu soruda öğretmen tartışılan durumdan hareketle öğrenenleri bir sonuca varmaya davet etmiştir. "Varsayıma yönlendirme" soruları ise öğrenenlerin bir durum ile ilgili varsayımsal ya da olasılıklı bir akıl yürütme yapmaya yönlendirildiği soru türüdür. Örneğin; ("O zaman dış görünüşlerinden yaşlı insanları anlar mıyız?") bu soruda konuşulan konudan hareketle gruptan varsayımsal akıl yürütme yaparak çıkarımda bulunmaları talep edilmektedir.

Tablo 10. Çıkarım amaçlı soru kategorisine ait gözlemlenen yüzdelik hesaplamalar ve z puanları

\begin{tabular}{lrr}
\hline Uygulama Sırası & Yüzde (\%) & z puanı \\
\hline Su Damlacıklarının Hikayeleri (Maddenin Halleri) & 8,33 & 0,91 \\
\hline Ağır ve Hafif Taşlar & 5,26 & $-0,58$ \\
\hline Mevsimler & 5,83 & $-0,30$ \\
\hline Dünyamız Nasıl Oluştu? & 2,68 & $-1,84$ \\
\hline Engelli Kimdir? & 8,57 & 1,03 \\
\hline Meslekler & 7,95 & 0,73 \\
\hline Yaramaz Topların Hikayesi (Yer çekimi) & 4,84 & $-0,79$ \\
\hline Kış Uykusuna Yatan Hayvanlar & 2,05 & $-2,15$ \\
\hline Iki Kafamız Olsa Ne Olurdu? & 6,67 & 0,10 \\
\hline Doğal Afetler & 2,61 & $-1,88$ \\
\hline
\end{tabular}

Çıkarım sorularının kullanım oranları incelendiğinde en az kullanımın "Dünyamız Nasıl Oluştu?" adlı uygulamada olduğu görülmektedir. Buna ek olarak değerlendirici ve çeldirici soruların daha fazla tercih edildiği "Doğal Afetler" ve "Kış Uykusuna Yatan Hayvanlar" uygulamalarında çıkarım amaçlı sorularının kullanımındaki azlık dikkat çekmektedir. Detaylandırılacak olursak; çıkarım amaçı öğretmen soruları uygulama bazlı olarak değişkenlik göstermiştir. Ancak bu değişkenlik için anlamlı bir çıkarım yapılamamıştır.

\section{Sonuç ve Öneriler}

Erken çocukluk eğitimcisinin sınıf içi öğretimsel süreçlerinin kaydedildiği bu çalışmada uygumalar söylemsel ve bağlamsal olarak incelenmiş ve her bir uygulamanın içeriğine soru kategorileri ve alt kategorileri bazında nitel yorumlamalar yapılmıştır. Araştırmada öğretmenin sorularının büyük çoğunluğunun iletişimsel kategoride olduğu tespit edilmiş ve bunların uygulama bazlı oranlarının incelenmesi sonucunda; uygulamanın doğasının, konusunun, müzakereye yatkınlığının, kültürel bağlamının ve öğrenenlerin ilgi-yeteneklerinin tartışmanın içeriğini ve gidişatını doğrudan etkilediği sonucuna ulaşılmıştır (Steiner, 1973). Buna ek olarak öğrenenlerin sınıfa getirdikleri sosyal dil ile bilim dilinin farklılaştığı ve bu aralığın özellikle erken çocukluk döneminde genişleyebildiği bu durumun bazı uygulamalarda iletişimsel soruların kullanımının artmasına sebep olduğu tespit edilmiştir. Bunun yanında izleme sorularının kombinasyonlu kullanımı ile toplam soru türevi kullanımlarının (değerlendirme, çeldirme, gözlem-karşılaştırma-tahmine yönlendirme vs.) daha homojen bir geçişte olduğu gözlenmiştir. Ayrıca değerlendirici soruların tartışmalarda etkin kullanımasının öğretmenin sınıftaki otoritesini paylaşmasına yardımcı olduğu tespit edilmiştir (Soysal ve Radmard, 2018). Bunun sonucunda kategorilerin ve alt kategorilerin uygulama bazlı olarak incelenmesinin öğretmene daha iyi bir geri bildirim mekanizması sağlayabileceği sonucuna ulaşılmıştır. Bu nedenle incelemelerin soru türevi bazında yapılamasının yanı sıra tüm hamlelerin (sözel ve sözel olmayan, jest-mimikler vs. gibi) gözlendiği daha detaylı ve derinlemesine analizler yapılmasının etkinliklerinin verimliliğiyle ilgili daha etkili geri bildirim mekanizmasını sağlayabileceğini düşündürmektedir. Ayrıca bu söylemsel hamlelerin öğrenenler tarafında ne tür bilişsel dalgalanmalara yol açabildiğini delilleriyle gösterebilmek öğretmenin pedagojik olarak mesleki eğitim süreçlerine daha çok bağlanabilmesine destek olacaktır. Bu bağlamda uygulamaların sistematik takibi ve bağlamsal çözümlenmesi öğretmen eğitimi ve farkındalığı noktalarında öğretmenlerin pedagojik ve öğretimsel olarak bilinçli sorumluluk almasını destekleyecektir (Franke ve Kazemi, 2001; Santagata, Zannoni ve Stigler, 2007). Buna ek olarak, etkinliklerin içeriklerinin yapılandırılması süreçlerinde sağlanan bu geri bildirimlerin öğretmenlere ve akademisyenlere yol gösterici nitelikte olabileceği düșünülmektedir. Tüm bunlara ek olarak öğretmen eğitiminin ve farkındalığının yaratıması için süreçlerinin daha planlı ve sistematik örgütlenmesinin mesleki gelişim programlarının oluşturulmasında ve genellenmesinde alana katkı sağlayabileceği düşünülmektedir (Barnhart ve van Es, 2011). Böylece öğretmenler; hem alan uzmanlarıyla birebir etkileşimde olabilecek hem de onların sınıf içi etkileşimlerini kendi sınıflarına uyarlayıp taşıyabilecektir. Bununla birlikte öğretmenler sahada yalnızca eğitim fakültelerinde aldığı teorik bilgilerle yetinmemiş olacaktır ve süreçleri delil temelli bir perspektifle yürütebilecektir (Sherin, Jacobs ve Philipp, 2011). 


\section{Yayın Etiği Beyanı}

Bu araştırmanın planlanma, uygulama ve raporlama süreçlerinin tamamında "Yükseköğretim Kurumları Bilimsel Araştırma ve Yayın Etiği Yönergesi" kapsamında uyulması belirtilen tüm kurallara uyulmuştur. Yönergenin ikinci bölümü olan "Bilimsel Araştırma ve Yayın Etiğine Aykırı Eylemler" başlığı altında belirtilen eylemlerden hiçbiri gerçekleştirilmemiştir. İstanbul Aydın Üniversitesi Etik Komisyonu'nun 2020/01 numaralı ve 28/01/2020 tarihli toplantısında yapılan görüşmeler ve değerlendirmeler sonucunda çalışmanın içeriğinde ve uygulanmasında etik açıdan bir sakınca olmadığına oy birliği ile karar verilmiştir.

\section{Kaynakça}

Atay, D. (2003). Öretmen adaylarına yansıtmayı öretmek: Portfolyo çalıması. Kuram ve Uygulamada Eitim Yönetimi, 9(36), 508-527.

Bay, N., \& Alisinanoğlu, F. (2012, Aralık). Okul öncesi eğitimi öğretmenlerine uygulanan soru sorma becerisi öğretim programının ögretmenlerin sorularının bilişsel taksonomisine etkisi. Mersin Üniversitesi Eğitim Fakültesi Dergisi, 8(3), 80-93.

Bakhtin, M. (1934). Discourse in the novel. the dialogic imagination: four essays. Michael Holguist and Caryl Emerson Austin: University of Texas.

Barnhart, T., \& van Es , E. (2015). Studying Teacher noticing: examining the relationship among pre-service science teachers' ability to attend, analyze and respond to student thinking. Teaching and Teacher Education, 45, 83-93.

Blatchford, I., \& Mani, L. (2008). Would you like to tidy up now? an analysis of adult questioning in the english foundation stage. Early Years, 28(1), 5-22.

Berland, L. K., \& Hammer, D. (2012). Framing for Scientific Argumentation. Journal of Research in Science Teaching, 49(1), 68-94.

Boyd, M., \& Galda, L. (2011). Real talk in elemantary classroms: effective oral language pactice. New York: The Guilford Press.

Chandler, P., \& Sweller, J. (1991). Cognitive load theory and the format of instruction. Cognition and Instruction, 8(4), 193-332.

Cheminais, R. (2008). Every Child matters: A practical guide for teaching assistants. New York: Reutledge Pres.

Chin, C. (2007). Teacher questioning in science classrooms: approaches that stimulate productive thinking. Journal of Research in Science Teaching, 44(6), 815-843.

Chin, C., \& Osborne, J. (2008). Studets question: A potential resource for teaching and learning science. Studies in Science Education, 41(1), 1-39.

Dantonio, C. (1990). How can we create thinkers? questioning strategies that work for teachers. Bloomington IN: National Educational Service.
De Rivera , C., Girolametto, J., \& Weitzman, E. (2005). Children's responses to educators' questions in day care play groups. American Journal of Speech-Language Pathology, 14, 14-26

de Rivera, C., Girolametto, L., Greenberg, I., \& Weitzman, E. (2005). Children's responses to educators' questions in day care play. American Journal of Speech-Language Pathology, 14(1), 14-26.

DeVries, R., Zan, B., Hildebrant, C., Edmiaston, R., \& Sales, C. (2002). Development constructivist early childhood cirriculum. New York: Teacher College Press.

Dovigo, F. (2016). Argumentation in preschool: A common ground for collaborative learning in early childhood. European Early Childhood Education Research Journal, 24(6), 818-840.

Doblaev, L. (1984). Studieteksten lezen en begrijpen (Reading and understanding stud texts). Netherlands: van Walraven.

Erickson, F. (2011). Mathematics teacher noticing: seeing through teachers' eyes. New York: Routledge.

Engle, R., \& Contant, F. (2002). Guiding Principles for Fostering Productive Disciplinary Engagement: Explaining an Emergent Argument in a Community of Learners Classroom. Cognition and Instuction, 20(4), 399-483.

Fairbain, D. (1987). The Art of Questioning Your Students. The Clearing House, 61(1), 19-22.

Fraenkel, J. R. \& Wallen, N.E (2009). How to design and evaluate research in education (7th ed). New York. McGrawhill.

Franke, M.L., \& Kazemi, E. (2001). Teaching as learning within a community of practice: Characterizing generative growth. In T. Wood, B. Nelson, \& J. Warfield (Eds.). Beyond classical pedagogy in elementary mathematics: The nature o facilitative teaching (pp. 47-74). Mahwah, NJ: Erlbaum.

Ford, M. J. (2008). Disciplinary authority and accountability in scientific practice and learning. Science Education, 92(3), 404- 423

Gall, M. (1984). Synthesis of research on teachers' questioning. Educational Leadership, 42(3), 40-47.

Gelfuso, A., \& Dennis, D. (2014). ). Getting Reflection off the page: the challenges of developing support for pre-service teacher reflection. Teaching and Teacher Education, 38(1), 1-11.

Good, T., \& Brophy, J. (1970). Teacher-child dyadic interactions: a new method of classroom observation. Journal of School Psychology, 8(2), 131-138.

Harlen, W. (1999). Effective teaching of science: a review of research. edinburgh. Scotland: Council for Reasearch in Education. 
Haves, R., \& Matusov, E. (2005). Designing for dialogue in place of teacher talk and student slience. Culture \& Psychology, 11(3), 339-357.

Jegede, O., \& Olajide, J. (1995). Waittime, classroom discourse, and the influence of sociocultural factors in science teaching. Science Education, 79(3), 233-249.

John-Steiner, V., \& Mahn, H. (1996). Sociocultural approaches to learning and development: A vygotskian framework. Educational Psychological, 31(3/4), 191-206.

Johnston, J., Halocha, J., \& Chater, M. (2007). Developing teaching skills in the primary school. America: Open University Press.

Joyce, B., \& Showers, B. (1983). Power in staff development through research on training. Alexandria, VA: Association for Supervision and Curriculum Development.

Kei, W., \& Wong, V. (2013). Metacognition in 3-6 years old: evidence from a kindergarden in Hong Kong. Asia Pasific Journal of Research in Early Chilhood Education, 7(1), 1-29.

Kiemer, K., Gröschner, A., Pehmer, A. K., \& Siedel, T. (2015). Effects of a classroom discourse intervention on teachers' practice and students' motivation to learn mathematics and science. Learning and Instruction, 35, 94-103.

Klein, E., Hammrich, P., Bloom, S., \& Ragins , A. (2000). Language development and science inquiry: The head start on science and communication program. Early Chilhood and Practice, 2(2), 1-22.

Lincoln, Y. S. , \& Guba, E. G. (1985). Naturlalistic inquiry. Beverly Hills, CA: Sage

MacNaughton, G., \& Williams, G. (2004). Teaching young children choices in teory and practice. Australia: Ligare Pty. Ltd.

Massey, S. L. (2004). Teacher-child conversation in the preschool classroom. Early Childhood Education Journal, 31(4), 227-231.

Massey, S., Pence, K., Justice L. M, \& Bowles, R. (2008). Educators' use of cognitively challenging questions in economically disadvantaged preschool classroom contexts. Early Education and Development, 19(2), 340360 .

Mercer, N. (2000). Words and minds: How we use language to think together. London: Routledge.

Mercer, N. (2008). The seeds of time: Why classroom dialogue needs a temporal analysis. The Journal of the Learning Sciences, 17(1), 33-59.

Merriam, S. (1998). Qualitative research and case study applications in education: Revised and expanded from case study research in education. San Francisco: Jossey-Bass.
Morris, A., Hiebert, J., \& Spitzer, S. (2009). Mathematical knowledge for teaching in planning and avuluating instruction: What can preservice teachers learn? Journal of Research in Mathematics Education, 40(5), 491-529.

Piaget, J. (1997). The moral judgement of the child. Simon and Schuster.

Pontecorvo, C., \& Sterponi, L. (2002). Learning to argue and reason through discourse in educational settings. Cultural-Historical Psychology, 4, 19-29.

Oers, v., Wardekker, E., \& van der Veer, R. (2010). The transformation of learning: Advances in cultural-historical activity theory. Cambridge University Press: Reissue Edition

Santagata, R., Zannoni , C., \& Stigler, J. (2007). The role of lesson analysis in pre-service teacher education: An empirical investigation of teacher learning from a virtual video-based field experience. Journal of Mathematics Teacher Education, 10, 123-140.

Savage, L. (1998). Eliciting critical thinking skills through questioning. Clearing House, 71(5), 291-293.

Sherin , M., Jacobs, V., \& Philipp, R. (2011). Mathematics teacher noticing: seeing through teachers' eyes. Mathematics Teacher Education, 10(2), 123-140.

Soysal, Y. (2018). Determining the mechanics of classroom discourse in Vygotskian sense: Teacher discursive moves reconsidered. Research in Science Education, $1-25$

Soysal, Y. (2019). Fen öğretiminde öğretmenin söylemsel hamlelerinin öğrenenlerinin akıl yürütme kalitelerine etkisi: Söylem analizi yaklaşımı. Eğitimde Nitel Araştırmalar Dergisi, 7(3), 994-1032.

Soysal, Y. (2019). Yüksek öğretimin ilkeleri üzerine pedagoji temelli bir söylem analizi Vygotskyci perspektif. İstanbul:Yüksek Öğretim Çalışmaları ve Araştırma Merkezi .

Soysal, Y. (2020). Establishing the norms of the Vygotskian teaching in the science classroom. Elemantary Education Online, 19(3), 1838-1857.

Soysal, Y., \& Radmard, S. (2018). Sınıf yönetimi olgusunun pedagoji, otorite tipleri söylemsel güç ilişkileri bağlamında yeniden değerlendirilmesi. Ulusal Eğitim Akademisi Dergisi, 2(2), 59-85

Star, J., \& Strickland, S. (2007). Learning to observe: using video to improve preservice teachers' ability to notice. Journal of Mathematics Teacher Education, 11, 107-125.

Storey, S. (2004). Teacher Questioning to improve early childhood reasoning (Doctoral dissertation), Department of Teaching and Teacher Education in Arizona University, USA.

Tsung-Hui, T., \& Wei-Ying, W. (2008). Preschool teacher-child verbal interactions in science teaching. Electronic Journal of Science Education, 12(2), 2-23. 
van der Veen, C., van Kruistum, C., \& Michaels, S. (2015). Productive classroom dialogue as an activity of shared thinking and communicating: A commentary on marsal. Mind Culture and Activity, 24(4), 320-325.

van Kleeck, A., Vander Woude, J., \& Hammet, L. (2006). Fostering literal and inferential language skills in head start preschoolers with language impairment using scripted book-sharing discussions. American Journal of Speech-Language Pathology, 15(1), 85-95.

van Oers, B. (2012b). Meaningful cultural learning by imitative participation: The case of abstract thinking in primary school. Human Development, 55, 136-158.

Vogler, J. (2005). Improve your verbal questioning. The Clearing House, 14(2), 98-103.

Vosniadou, S. (1994). Capturing and modeling the process of conceptual change. Learning and Instruction, 4, 45-69.

Vosniadou, S., \& Brewer, W. (1992). Mental models of the earth: a study of conceptual change in chilhood. Cognitive Psyhology, 24, 535-585.

Vygotsky, L. (1987). Imagination and its development in childhood. The collected works of LS Vygotsky, 1, 339-350.,

Wegerif, R. (2008). Reason and dialogue in education. In van Oers, B., Elbers, E., van der Veer, R., Wardekker, W. (Eds.), The transformation of learning (pp. 273-285. Cambridge, UK: Cambridge University Press.

Wilen, W., \& Clegg, A. (1986). Effective questions and questioning: A research review. Theory \& Research in Social Education, 14(2), 153-161.

Wragg, E., \& Brown, G. (2001). Questioning in the primary school (Successful teaching). London: Routledge Falmer.

Yolder, P., Davies, B., Bishop , K., \& Munson , L. (1994). Effect of adult continuing wh-questions on conversational participation in children with developmental disabilities. Journal of Speech \& Hearing Research, 37(1), 193203.

Zucker, T., Justice, L., Piasta, S., \& Kaderavek, J. (2010). Preschool teachers' literal and inferential questions and children's responses during whole-class shared reading. Early Childhood Research Quarterly, 25(1), 65-83. 